\title{
Prediction of Shear Strength of Reinforced Recycled Aggregate Concrete Beams without Stirrups
}

\author{
Monthian Setkit ${ }^{1}$, Satjapan Leelatanon ${ }^{1, *}$, Thanongsak Imjai ${ }^{1, *} \mathbb{D}$, Reyes Garcia ${ }^{2} \mathbb{D}$ and Suchart Limkatanyu ${ }^{3}$ \\ 1 Center of Excellence in Sustainable Disaster Management, School of Engineering and Technology, \\ Walailak University, Nakhonsithammarat 80161, Thailand; smonthia@wu.ac.th \\ 2 School of Engineering, The University of Warwick, Coventry CV4 7AL, UK; reyes.garcia@warwick.ac.uk \\ 3 Department of Civil Engineering, Prince of Songkla University, Songkhla 90110, Thailand; suchart.1@psu.ac.th \\ * Correspondence: lsatjapa@wu.ac.th (S.L.); thanongsak.im@wu.ac.th (T.I.); Tel.: +66-(0)-7567-2378 (S.L. \& T.I.)
}

check for updates

Citation: Setkit, M.; Leelatanon, S.; Imjai, T.; Garcia, R.; Limkatanyu, S Prediction of Shear Strength of Reinforced Recycled Aggregate Concrete Beams without Stirrups. Buildings 2021, 11, 402. https:// doi.org/10.3390/buildings11090402

Academic Editor: Pavel Reiterman

Received: 4 August 2021

Accepted: 6 September 2021

Published: 8 September 2021

Publisher's Note: MDPI stays neutral with regard to jurisdictional claims in published maps and institutional affiliations.

Copyright: (c) 2021 by the authors. Licensee MDPI, Basel, Switzerland. This article is an open access article distributed under the terms and conditions of the Creative Commons Attribution (CC BY) license (https:// creativecommons.org/licenses/by/ $4.0 /)$.

\begin{abstract}
For decades, recycled coarse aggregate (RCA) has been used to make recycled aggregate concrete (RAC). Numerous studies have compared the mechanical properties and durability of recycled aggregate concrete (RAC) to those of natural aggregate concrete (NAC). However, test results on the shear strength of reinforced recycled aggregate concrete beams are still limited and sometimes contradictory. Shear failure is generally brittle and must be prevented. This article studies experimentally and analytically the shear strength of reinforced RAC beams without stirrups. Eight RAC beams and two controlled NAC beams were tested under the four-point flexural test with the shear span-to-effective depth ratio $(a / d)$ of 3.10. The main parameters investigated were the replacement percentage of RCA $(0 \%, 25 \%, 50 \%, 75 \%$, and $100 \%)$ and longitudinal reinforcement ratio $\left(\rho_{\mathrm{W}}\right)$ of $1.16 \%$ and $1.81 \%$. It was found that the normalized shear stresses of RAC beams with $\rho_{\mathrm{w}}=1.81 \%$ at all levels of replacement percentage were quite similar to those of the NAC counterparts. Moreover, the normalized shear stress of the beam with $100 \%$ RCA and $\rho_{\mathrm{W}}=1.16 \%$ was only $6 \%$ lower than that of the NAC beam. A database of 128 RAC beams without shear reinforcement from literature was analyzed to evaluate the accuracy of the ACI 318-19 shear provisions in predicting the shear strength of the beams. For an RCA replacement ratio of between $50 \%$ and $100 \%$, it was proposed to apply a reduction factor of 0.75 to the current ACI code equation to account for the physical variations of RCA, such as replacement percentage, RCA source and quality, density, amount of residual mortar, and physical irregularity.
\end{abstract}

Keywords: recycled coarse aggregate (RCA); recycled aggregate concrete (RAC); construction waste; shear strength

\section{Introduction}

Concrete is the most widely used construction material in the world. With new construction and demolition of old buildings and structures, construction and demolition waste (CDW) are increasingly becoming an environmental problem. The production of new concrete also poses the problem of natural resource depletion due to the production of cement and to the extraction of natural coarse aggregates. Several studies exist on recycling construction and demolition waste to decrease the consumption demand of natural resources and reduce construction waste [1-4]. Since the largest source of CDW is concrete, numerous research studies have also examined the use of recycled coarse aggregate (RCA) to produce recycled aggregate concrete (RAC), of which the mechanical properties and durability are typically compared to those of natural coarse aggregate concrete (NAC) [5-13]. This is because coarse aggregate is the main concrete component, constituting about $60 \%$ to $75 \%$ of concrete volume. However, several test results are discouraging as they found that the properties of concrete with RCA were inferior to those of concrete with NCA [5,14-18]. 
Subsequent studies, therefore, focused on optimizing the concrete mixture proportions and on developing techniques to improve the quality of RCA [19-21]. For example, Fathifazl et al. proposed the Equivalent Mortar Volume (EMV) method to proportion concrete mixtures with RCA [22]. Katz [23] improved RCA using a silica fume solution and ultrasonic cleansing. Li et al. [24] coated RCA with pozzolanic powder to enhance the slump and strength of concrete.

Despite the above efforts, the use of RCA is generally limited to non-structural applications, such as road subbase and backfills. Indeed, the use of RCA in structural components is still limited because of skepticism toward recycling materials and the lack of guidelines. However, the environmental agenda is pushing the construction industry to find alternatives for the use of RCA in structural components. For instance, several studies have been conducted to investigate the shear strength of RAC beams tested in four-point bending. Sogo and Sato [25] conducted tests on the shear strength of RC beams with 100\% RCA. The beams were cast with or without shear reinforcement. Their experimental results indicated a 20\% decrease in shear strength. Etxeberria and Vazquez [26] tested twelve beams, with and without stirrups, using different RCA percentages of $0 \%, 25 \%, 50 \%$, and $100 \%$. Their results indicated that the shear strength of beams was not influenced by low percentages of RCA replacement (25\%). Gonzalez-Fonteboa and Martinez-Abella [27] reported the shear strength of four tested beams with 50\% RCA. The shear strength of RAC beams showed an insignificant difference compared to the controlled NAC beams. Knaack and Kurama [28] and Ignjatovic et al. [29] also reported that the effect of RCA on the shear strength was very small. On the other hand, studies by Arezoumandi et al. [30,31], Rahal and Alrefaei [32], Etman et al. [33], and Pradhan et al. [34] reported contradictory results: the shear strengths of the tested beams were lower than those from NAC counterparts. It should be noted that, in this study, the term "shear strength" is not concerned with the direct shear strength of the beams. Instead, it is associated with the combination of shears and flexural stresses. The failure of the beams tested in the abovementioned studies resulted from diagonal tension stresses, which combined the effects of shear stresses and longitudinal flexural stresses resulting from the four-point bending test setup typically adopted in experimental programs.

The shear behavior (and shear strength) of reinforced concrete beams is a complex phenomenon, and therefore numerous tested data must be collected and analyzed to develop suitable guidelines. As such, previous research also attempted to conduct more tests on the shear strength of RAC beams so as to compare their results to existing design equations. Several parameters were found to influence shear strength, such as percentage of RCA replacement, size of the beam, concrete compressive strength, shear span-toeffective depth ratio, and longitudinal reinforcement ratio [34]. However, further research is still necessary to assess the accuracy of current design guidelines in predicting the shear strength of RAC beams with and without shear reinforcement.

This article investigates the shear strength of RAC beams without stirrups. The percentage of RCA replacement and longitudinal reinforcement ratios were selected as variables. The levels of RCA substitution were $0 \%, 25 \%, 50 \%, 75 \%$, and $100 \%$. Longitudinal reinforcement ratios of $1.16 \%$ and $1.81 \%$ were chosen. The shear strengths of two NAC beams and eight RAC beams without stirrups on one-third of the beam span were experimentally investigated. Subsequently, test results of RAC beams without stirrups from other studies [22,26-42] were compiled and analyzed to evaluate the accuracy of the existing ACI 318-19 shear provision at predicting the strength of the beams. Finally, a modification factor is proposed to account for the physical variations of RCA, such as replacement percentage, RCA source and quality, density, amount of residual mortar, and physical irregularity.

\section{Material and Methods}

The experimental program involves the testing of ten reinforced concrete beams without shear reinforcement on one-third of the beam span. Materials, mixture proportions, and details of specimens are described below. 


\subsection{Materials Properties}

The materials used to cast the beams included Type 1 Ordinary Portland Cement (OPC), natural coarse aggregate (NCA), recycled coarse aggregate (RCA), fine aggregate (FA), water, and superplasticizer (SP). The RCA came from a crushed (previously tested) $150 \times 300 \mathrm{~mm}$ concrete cylinder with a compressive strength of approximately $24-30 \mathrm{MPa}$ (Figure 1a). A low cost, custom-made jaw crusher machine, developed at Walailak University, was able to crush the waste concrete with a maximum feeding size of $150 \mathrm{~mm}$. The AC220-volts jaw crusher machine can produce adjustable discharges of sizes 10-40 mm with the capacity of 1-3 tons/h [43] (Figure 1b). The RCA was sieved to sizes of $9 \mathrm{~mm}$, $12 \mathrm{~mm}$, and $19 \mathrm{~mm}$ (Figure 1c,d). The properties of NCA and RCA used in this study are listed in Table 1.

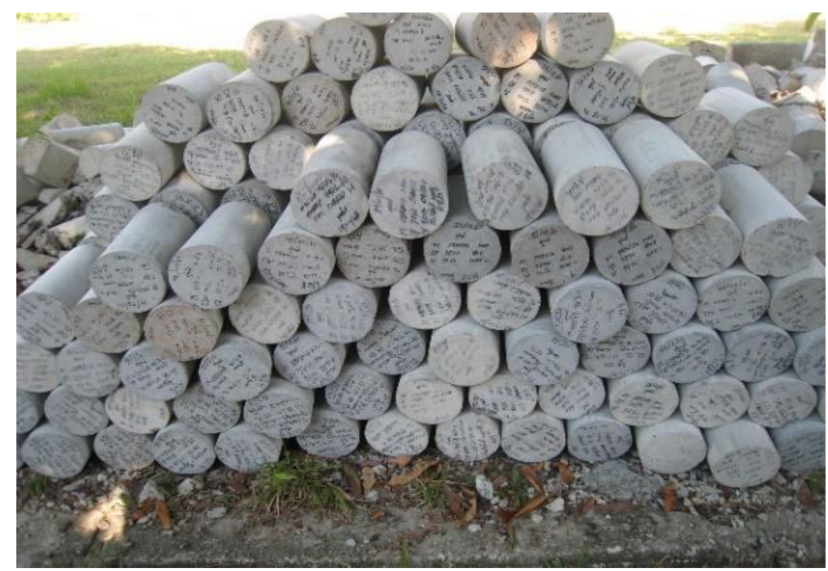

(a)

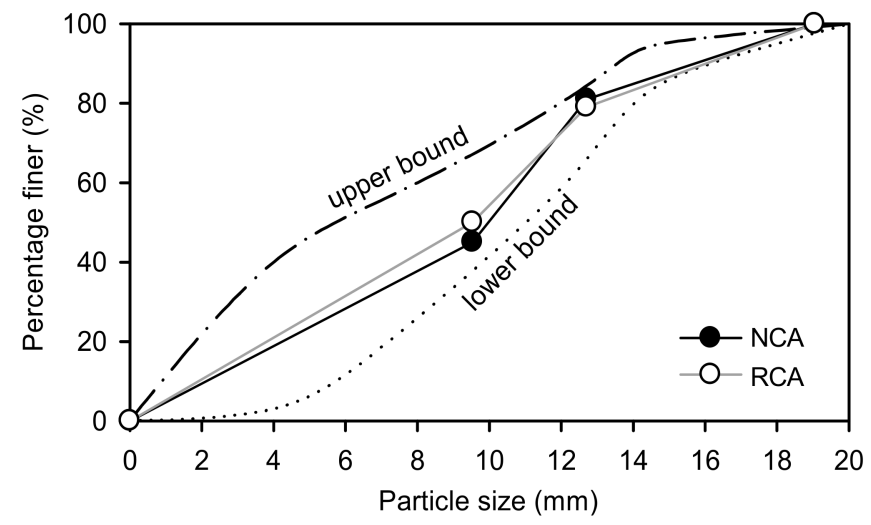

(c)

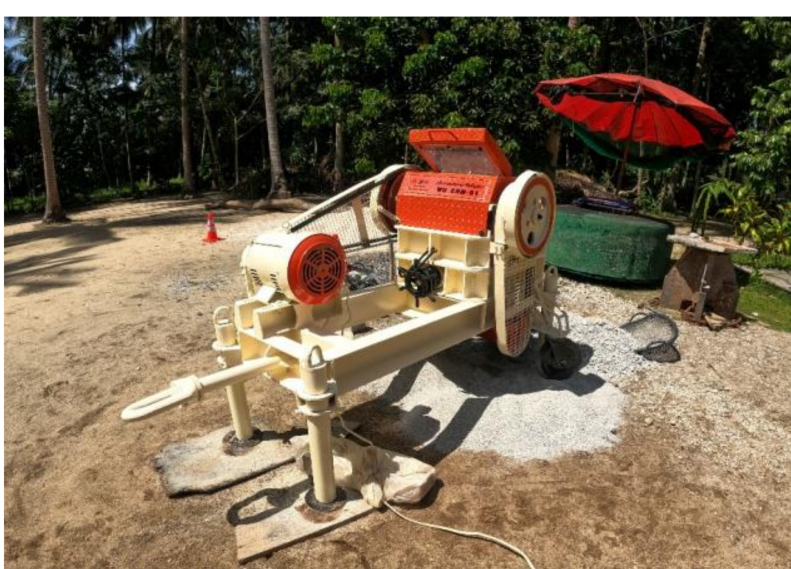

(b)

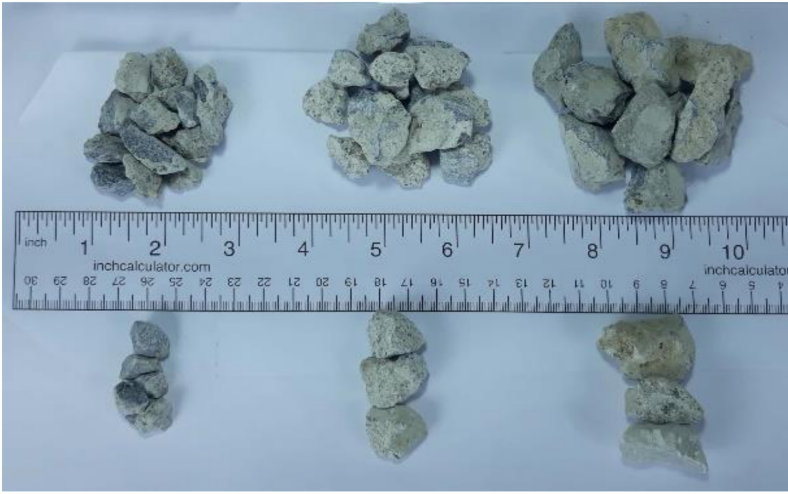

(d)

Figure 1. (a) Concrete cylinder waste (b) Custom-made crushing machine (c) Coarse aggregate sieving test results, and (d) View of recycled coarse aggregate (RCA).

The diameters of steel used as longitudinal reinforcement were $16 \mathrm{~mm}$ and $20 \mathrm{~mm}$. The beams were reinforced with $6 \mathrm{~mm}$ stirrups on two-thirds of the beam span. The remaining one-third of the span did not include stirrups. The yield stress and ultimate stress of the reinforcing steel are shown in Table 2.

\subsection{Concrete Mixture Proportions}

Following ACI 211.1 [17], five mixes were designed with a water-cement ratio of 0.5 and a targeted compressive strength of $30 \mathrm{MPa}$ and a slump of $150 \mathrm{~mm}$. The mix proportions of the five mixes are shown in Table 3. As shown in Table 1, RCA had lower specific gravity and unit weight, but higher water absorption and moisture. Therefore, water was adjusted to compensate for water content in recycled aggregate concrete due 
to the higher absorption and moisture. Superplasticizer (SP) was also utilized to increase workability in both NCA and RCA mix.

Table 1. Physical properties of fine, natural and recycled aggregates.

\begin{tabular}{cccc}
\hline Properties & FA & NCA & RCA \\
\hline Bulk Specific Gravity (SSD) & 2.6 & 2.7 & 2.43 \\
Unit Weight $\left(\mathrm{kg} / \mathrm{m}^{3}\right)$ & & 1730 & 1397 \\
Water Absorption (\%) & 1.05 & 0.28 & 4.59 \\
Moisture (\%) & 1.35 & 0.61 & 2.24 \\
Fineness Modulus & 2.7 & & \\
Max. size (mm) & 4.76 & 19.1 & 18.6 \\
Impact value (\%) & & 10.15 & 13.4 \\
Crushing value (\%) & & 21.77 & 23.12 \\
Residual mortar (\%) & & 32.5 \\
\hline
\end{tabular}

Table 2. Mechanical properties of steel reinforcement.

\begin{tabular}{cccc}
\hline Nominal Size (mm) & Yield Stress $\mathbf{( M P a )}$ & Ultimate Stress $\mathbf{( M P a )}$ & Elongation (\%) \\
\hline 20 & 519 & 668 & 18 \\
16 & 561 & 658 & 21 \\
6 & 424 & 639 & 28 \\
\hline
\end{tabular}

Table 3. Concrete mixture proportions (in $\mathrm{kg} / \mathrm{m}^{3}$ ).

\begin{tabular}{ccccccc}
\hline Mix Type & Cement & FA & NCA & RCA & Water & SP \\
\hline NCA & 357 & 719 & 1069 & & 190 & 1.07 \\
25\% RCA & 357 & 750 & 802 & 216 & 190 & 1.07 \\
$50 \%$ RCA & 357 & 780 & 535 & 432 & 190 & 1.07 \\
$75 \%$ RCA & 357 & 810 & 267 & 648 & 190 & 1.07 \\
$100 \%$ RCA & 357 & 840 & & 864 & 190 & 1.07
\end{tabular}

Note: FA is the fine aggregate, NCA is the natural coarse aggregate, RCA is the recycled coarse aggregate, and SP is the superplasticizer.

\subsection{Details of Test Beams}

Figure 2 depicts the details and test setup of beam specimens. The beams had a total length of $2.8 \mathrm{~m}$, a rectangular cross-section of $200 \mathrm{~mm}$ wide and $300 \mathrm{~mm}$ high, and an effective depth of $260 \mathrm{~mm}$. The beams had an effective test span of $2.4 \mathrm{~m}$ and a shear spanto-effective depth ratio of 3.1. The percentage of RCA replacement and the longitudinal reinforcement ratio in beams were used as parameters in the study. Two beams were fabricated from NCA, while eight beams were cast with RCA $(25 \%, 50 \%, 75 \%$, and $100 \%)$. The specimens were organized into two groups defined by two longitudinal reinforcement ratios $\left(\rho_{\mathrm{w}}\right)$. The first group consisted of five beams reinforced with three 16-mm deformed bars in the tension zone ( $\left.\rho_{\mathrm{w}}=1.16 \%\right)$. The second group used longitudinal reinforcement of three $20-\mathrm{mm}$ deformed bars $\left(\rho_{\mathrm{w}}=1.81 \%\right)$. One third of the beam span did not contain stirrups, in order to induce shear failure in this region. Stirrups were installed on the remaining two-thirds of the beam span to prevent shear failure on this side of the beam.

The IDs of the beam specimens began with 'RCA' followed by their RCA percentages. The longitudinal bar size was added at the end of the ID to distinguish different longitudinal reinforcement ratios. For instance, RCA0-DB20 was a beam without RCA, but with three 20-mm longitudinal bars $\left(\rho_{\mathrm{w}}=1.81 \%\right)$. Likewise, RCA25-DB16 indicated that the beam incorporated $25 \%$ RCA and three 16-mm longitudinal bars $\left(\rho_{\mathrm{W}}=1.16 \%\right)$. 


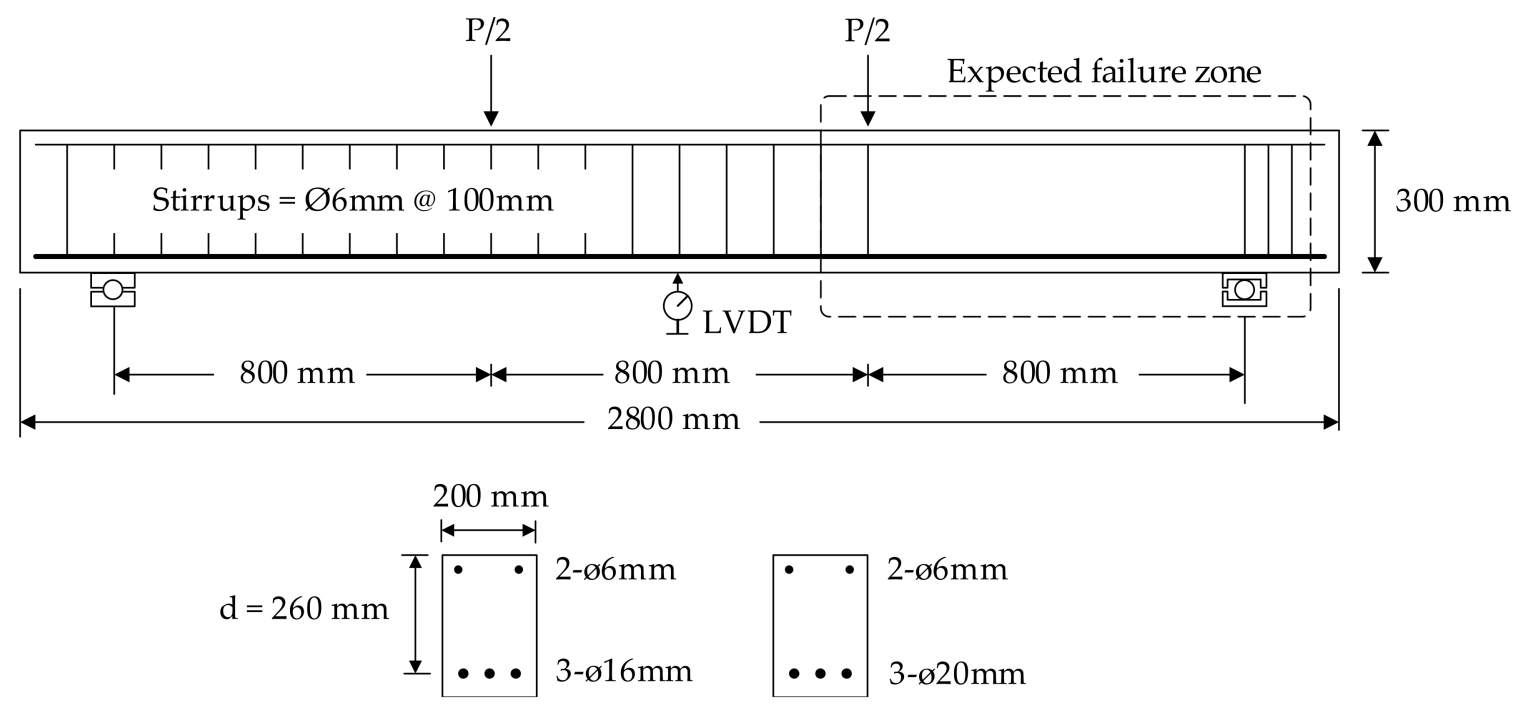

Figure 2. Test setup and details of beam specimens.

\subsection{Test Setup and Procedure}

The beams were tested in four-point bending. In this test setup, shear and flexural stresses were expected to develop and cause a diagonal tension failure on the beam region without stirrups. The beams were supported on a roller and pin support, located $200 \mathrm{~mm}$ from each end of the beams. Two linear variable differential transformers (LVDT-AEP TLDT50mm) were installed at mid-span to monitor the deflection of the beams. Load and deflection were recorded by a data acquisition system (KYOWA EDX-10 Series). The load was slowly applied by an electrically controlled hydraulic jack and monitored through a load cell of $1000 \mathrm{kN}$ (AEP Transducer-CTC4230100T5). The load was applied through a transfer beam resting on two supports on the top of the specimens. The load was applied continuously until the beams failed. On the testing day, six concrete cylinders were also tested to determine the compressive strength of concrete.

\section{Results and Discussion}

A summary of test results is shown in Table 4 . This section discusses the main results observed in this study.

Table 4. Summary of the test results.

\begin{tabular}{|c|c|c|c|c|c|c|c|c|}
\hline Specimen ID & $\begin{array}{c}f^{\prime}{ }_{c} \\
(\mathrm{MPa})\end{array}$ & $\begin{array}{l}\rho_{\mathrm{w}} \\
(\%)\end{array}$ & $\begin{array}{c}P_{u} \\
(\mathbf{k N})\end{array}$ & $\begin{array}{c}\Delta_{\mathrm{u}} \\
(\mathrm{mm})\end{array}$ & $\begin{array}{l}\text { Shear Crack } \\
\text { Inclination } \\
\text { Angle (Degree) }\end{array}$ & $\begin{array}{l}V_{\text {test }} \\
(\mathbf{k N})\end{array}$ & $\begin{array}{c}v_{t e s t}=V_{\text {test }} / b d \\
(\mathrm{MPa})\end{array}$ & $v_{t e s t} / \sqrt{f_{c}^{\prime}}$ \\
\hline RCA0-DB16 & 29.9 & 1.16 & 125 & 5.9 & 38 & 62.5 & 1.20 & 0.220 \\
\hline RCA25-DB16 & 35.7 & 1.16 & 135 & 6.5 & 31 & 67.5 & 1.29 & 0.217 \\
\hline RCA50-DB16 & 29.0 & 1.16 & 119 & 6.2 & 31 & 59.5 & 1.14 & 0.212 \\
\hline RCA75-DB16 & 32.9 & 1.16 & 125 & 5.8 & 31 & 62.5 & 1.20 & 0.209 \\
\hline RCA100-DB16 & 31.9 & 1.16 & 122 & 5.9 & 36 & 61.0 & 1.17 & 0.208 \\
\hline RCA0-DB20 & 29.7 & 1.81 & 166.6 & 6.8 & 38 & 83.3 & 1.60 & 0.294 \\
\hline RCA25-DB20 & 30.7 & 1.81 & 167.8 & 6.2 & 32 & 83.9 & 1.61 & 0.291 \\
\hline RCA50-DB20 & 23.1 & 1.81 & 145 & 5.5 & 31 & 72.5 & 1.39 & 0.290 \\
\hline RCA75-DB20 & 34.1 & 1.81 & 175 & 6.5 & 31 & 87.5 & 1.68 & 0.289 \\
\hline RCA100-DB20 & 29.5 & 1.81 & 162.4 & 6.3 & 30 & 81.2 & 1.56 & 0.287 \\
\hline
\end{tabular}

\subsection{Ultimate Capacity and Failure Behaviour}

All tested beams failed in shear, as illustrated in Figure 3. Table 4 summarizes the cylindrical compressive strength, the ultimate load, $P_{u}$, and shear force at failure $V_{\text {test }}$ (i.e., half of $P_{u}$ ). At cracking loads of approximately $40 \mathrm{kN}$ and $50 \mathrm{kN}$ for DB16 and DB20 
series, flexural cracks developed at mid-span but these were very small. At ultimate load, an inclined crack suddenly appeared and caused the failure of the beams. The diagonal cracks for all beams were similar. The diagonal cracks of NAC beams were approximately 38 degrees, while crack angles of RAC beams were between 30 to 36 degrees. All of the beams failed in shear when the inclined flexural-shear crack propagated to the beam compression zone. At ultimate load, the lower tip of diagonal crack also penetrated towards the support. The mode of failures of the RAC beams was similar to that of beams tested in previous studies $[27,29,31]$.
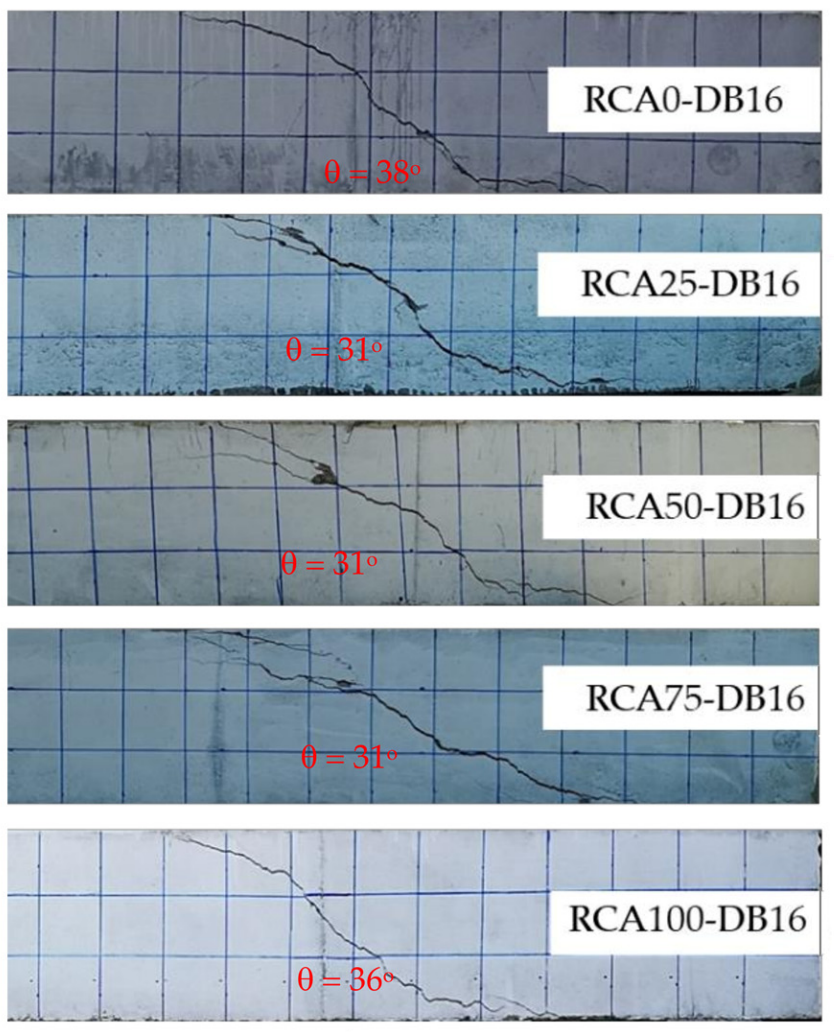
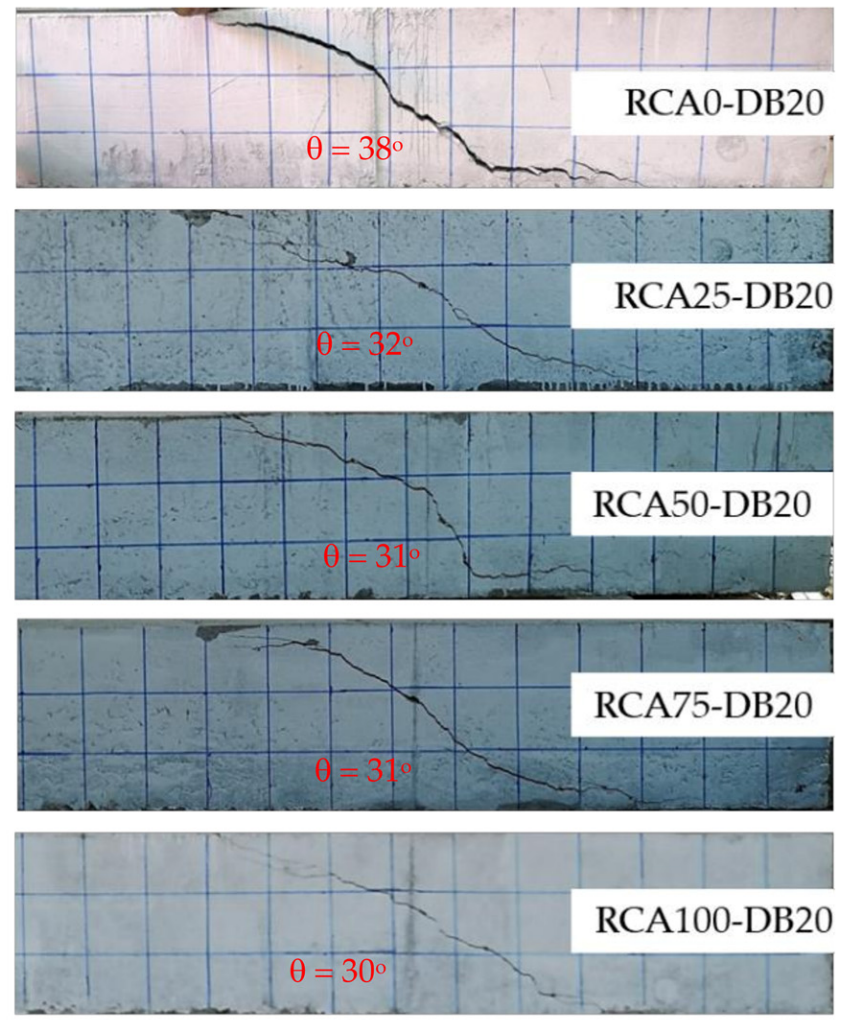

Figure 3. Failure of tested beams due to diagonal tension.

\subsection{Load-Deflection Responses}

The load-deflection relations of all tested beams are shown in Figures 4a and 5a for the beams with $\rho_{\mathrm{w}}=1.16 \%$ and $1.81 \%$, respectively. Before the first flexural cracks, all beams behaved in a linear elastic manner. Beams in the DB16 series $\left(\rho_{\mathrm{w}}=1.16 \%\right)$ lost some stiffness at the first cracking loads of approximately $40 \mathrm{kN}$. For beams in the DB20 series $\left(\rho_{\mathrm{w}}=1.81 \%\right)$, the first cracking loads were about $50 \mathrm{kN}$, at which point the beams' stiffness started to degrade. The deflections of all tested beams were limited and less than $7 \mathrm{~mm}$. These results were similar to tests reported by other researchers [30,32,39], as the beams failed in shear before the yielding of the longitudinal reinforcement. It was also reported that additional deformation due to shear cracks increase the overall deflection of the beam by up to $25 \%$ after the formation of shear cracks [44].

As expected, the ultimate loads and shear forces were higher in the beams with a higher longitudinal reinforcement ratio. These results confirmed the effect of longitudinal reinforcement ratio on the shear strength of concrete, which has been recently included in ACI 318-19. The difference in the deflections of RAC and NAC beams was not noticeable in the test, which was similar to tests reported by previous studies $[27,38]$. However, other researchers reported differences in deflections between RAC and NAC beams [32,45]. 


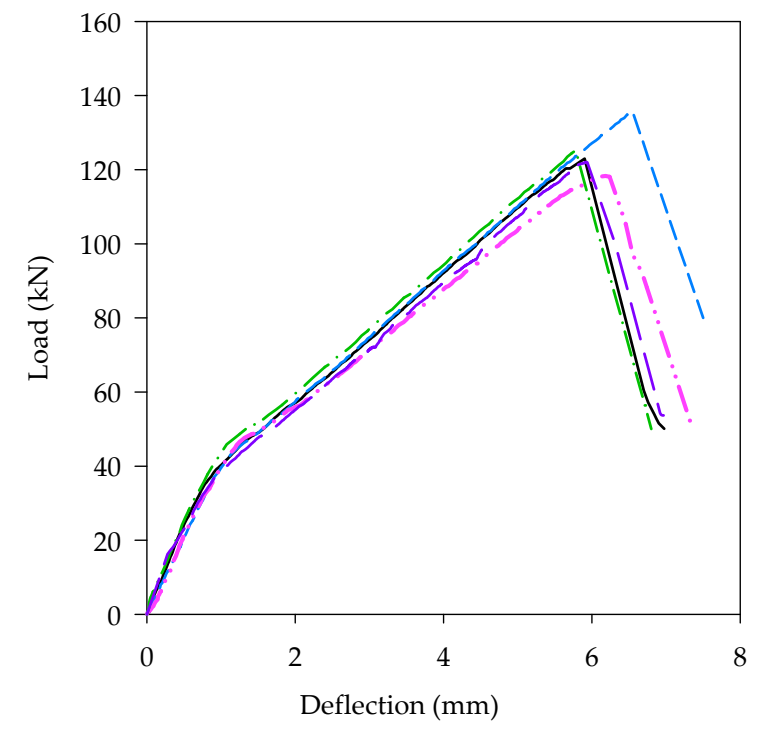

(a)

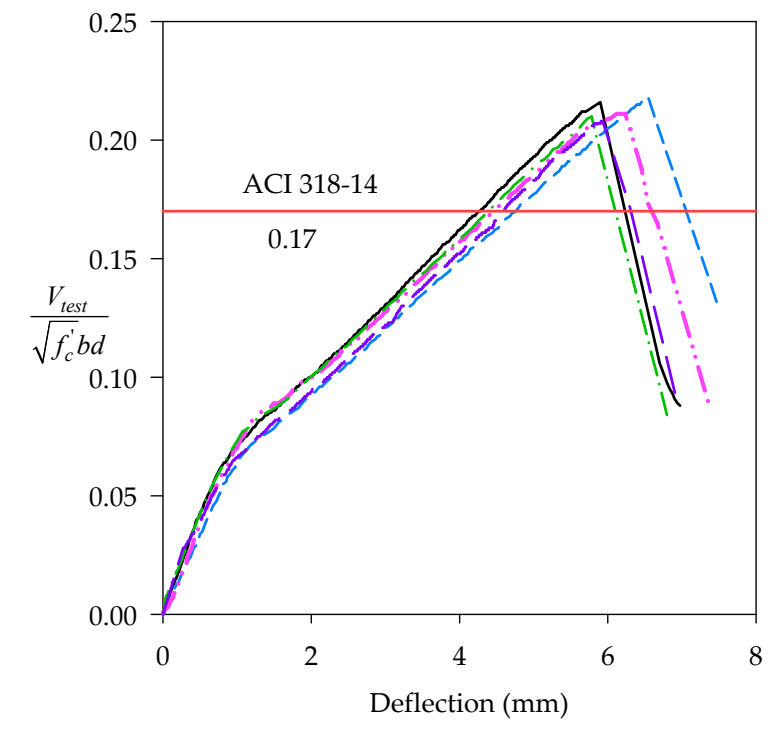

(b)

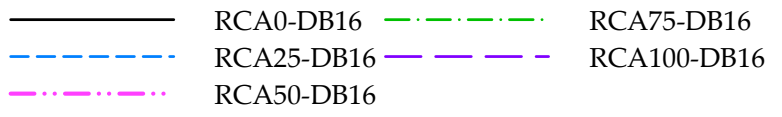

Figure 4. (a) Load-deflection curve for beams with reinforcement ratio, $\rho_{\mathrm{W}}=1.16 \%$, and (b) Normalized shear stress vs. deflection for beams with reinforcement ratio, $\rho_{\mathrm{w}}=1.16 \%$.

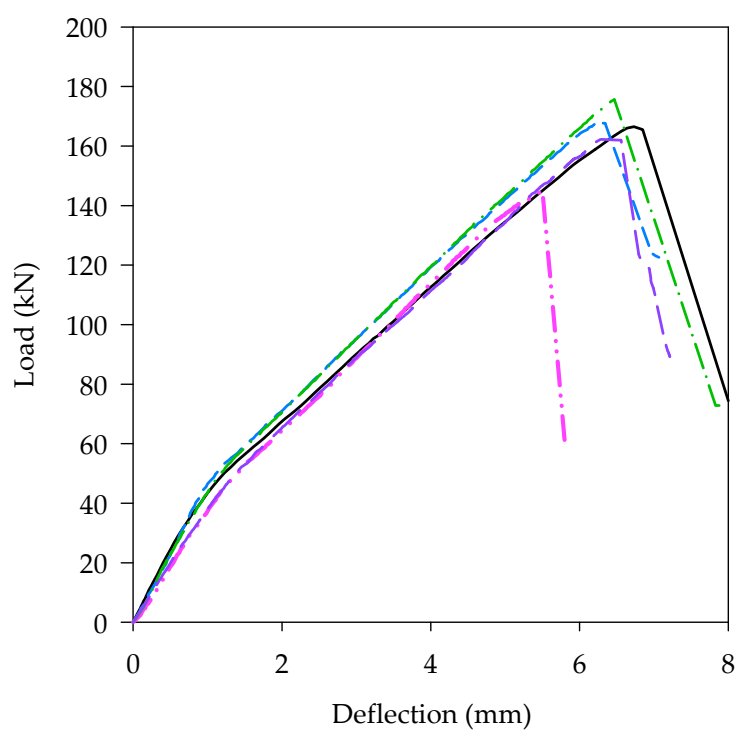

(a)

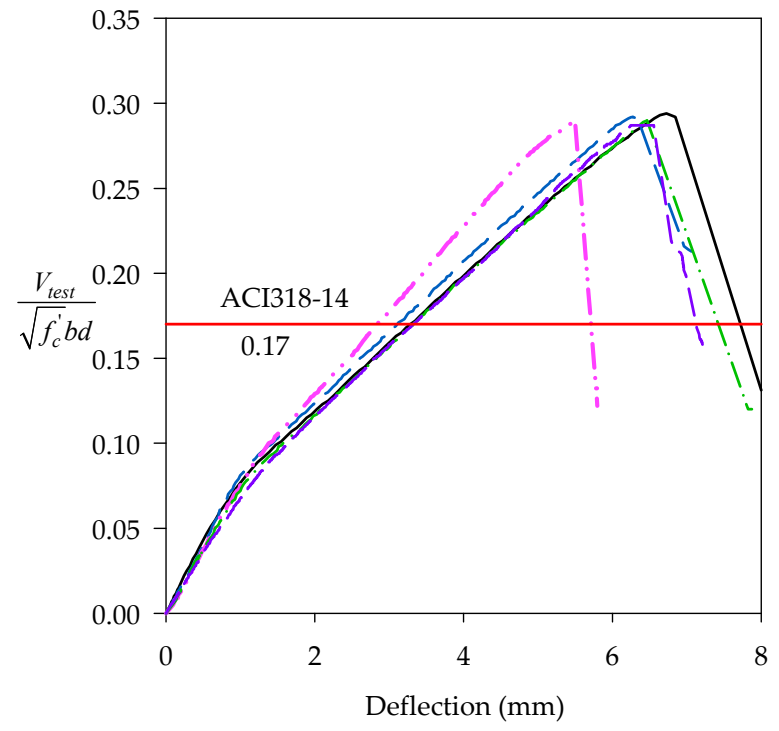

(b)

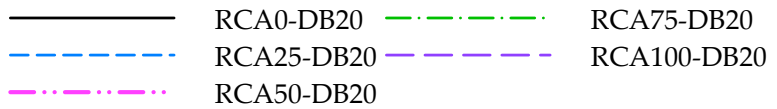

Figure 5. (a) Load-deflection curve for beams with reinforcement ratio, $\rho \mathrm{w}=1.81 \%$, and (b) Normalized shear stress vs. deflection for beams with longitudinal reinforcement ratio, $\rho_{\mathrm{w}}=1.81 \%$.

Figures $4 \mathrm{~b}$ and $5 \mathrm{~b}$ show the responses of beams in terms of average shear stress $\left(V_{\text {test }} / b d\right)$ normalized by the square root of the concrete cylinder strength, $f_{c}^{\prime} . V_{\text {test }}$ represents ultimate shear in $\mathrm{N}, f_{c}^{\prime}$ represents the concrete compressive strength in $\mathrm{MPa}, b$ represents the width of beam section (in $\mathrm{mm}$ ), and $d$ represents effective depth (in $\mathrm{mm}$ ). These figures allow comparisons of shear strength with different concrete compressive strengths. Figure 6 shows the ratios of normalized shear stress in the RAC and NAC beams. From Figures $4 \mathrm{~b}$ and 6 , the differences in normalized shear stress between the RAC and NAC 
beams were less than $6 \%$ for the beams with $\rho_{\mathrm{w}}=1.16 \%$ (DB16 series). It was also observed that the amount of RCA slightly affected the normalized shear stresses of the tested beams. The normalized shear stresses of the beams in this latter series were approximately 0.21 . According to ACI 318-14 shear provisions, the normalized shear stress of RC beams is 0.17 . It was evident that all RAC beams with $\rho_{\mathrm{w}}=1.16 \%$ had normalized shear stress higher than the ACI 318-14 shear equation. From Figures $5 \mathrm{~b}$ and 6 , a similar trend was observed for beams with $\rho_{\mathrm{W}}=1.81 \%$ (DB20 series). Normalized shear stresses of the NAC and RAC beams in this series were approximately 0.29 , and the amount of RCA barely affected the normalized shear stress of the tested beams, as shown in Figure 6. These results contradicted several previous tests by other researchers [30-34], which reported much lower shear strength in RAC beams compared to NAC beams. However, some researchers reported similar shear strength in RAC and NAC beams $[28,29]$. To the author's knowledge, the disagreement of test results may be attributed to the source and quality of concrete waste used to produce RCA. In this study, RCA was obtained by crushing good quality concrete waste with an approximate compressive strength of $30 \mathrm{MPa}$.

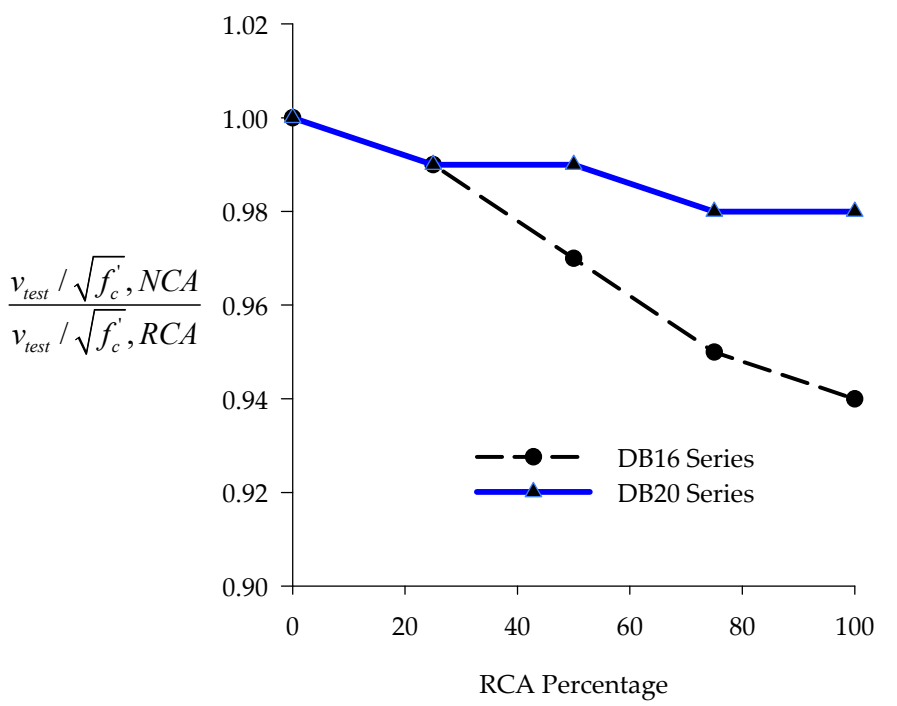

Figure 6. The ratio of normalized shear stress between RAC and NAC beams with different amounts of RCA.

\section{Prediction of Concrete Shear Strength}

On the basis of the considerations above, and to facilitate the rapid adoption of RCA in concrete construction, the current $\mathrm{ACI}$ equation to predict the shear strength of concrete members without stirrups was empirically investigated. In this study, the equation included in the ACI design guideline was modified using an empirical parameter based on extensive test data available in the literature. As seen in the following, the current ACI shear equation to calculate concrete shear strength $\left(v_{c}\right)$ was investigated. In order to allow for easier comparisons, the partial safety factors for material, as well as load and resistance factors adopted by the different design standards, are not included in the equation below.

\subsection{Ultimate Concrete Shear Strength}

Table 5 summarizes the test results of the beams and compares them to the shear strength predicted by the ACI 318-14 simplified shear equation and the ACI 318-19 shear provisions. The shear strength calculated by ACI 318-14 is shown in Table 5, column 6 . The ACI 318-14 simplified shear equation is defined as:

$$
V_{c}=0.17 \sqrt{f_{c}^{\prime}} b d
$$


where $V_{c}$ is the shear provided by concrete $(\mathrm{N}), f_{c}^{\prime}$ is the specified compressive strength of concrete cylinder (in MPa), $b$ is the width of cross-section (in $\mathrm{mm}$ ), and $d$ is the effective depth (in mm). This simplified shear equation has been utilized for several decades and is still being used in shear calculations in some countries. Therefore, the shear strength of the tested beams was also compared to this legacy equation.

Table 5. Summary of concrete and beam test results.

\begin{tabular}{|c|c|c|c|c|c|c|c|c|}
\hline Specimen ID & $\begin{array}{c}f_{c}^{\prime} c \\
(\mathbf{M P a})\end{array}$ & $\begin{array}{l}\rho_{\mathbf{w}} \\
(\%)\end{array}$ & $\begin{array}{c}\text { Ultimate Load } \\
\qquad P_{u}(\mathrm{kN})\end{array}$ & $V_{\text {test }}(\mathbf{k N})$ & $\begin{array}{c}V_{c}(\mathbf{k N}) \\
\mathrm{ACI} 318-14\end{array}$ & $\begin{array}{c}V_{\text {test }} / V_{c} \\
\text { ACI 318-14 }\end{array}$ & $\begin{array}{c}V_{c}(\mathbf{k N}) \\
\text { ACI 318-19 }\end{array}$ & $\begin{array}{c}V_{t e s t} / V_{c} \\
\text { ACI 318-19 }\end{array}$ \\
\hline (1) & (2) & (3) & (4) & (5) & (6) & (7) & (8) & (9) \\
\hline RCA0-DB16 & 29.9 & 1.16 & 125 & 62.5 & 48.35 & 1.29 & 42.07 & 1.49 \\
\hline RCA25-DB16 & 35.7 & 1.16 & 135 & 67.5 & 52.85 & 1.28 & 45.99 & 1.47 \\
\hline RCA50-DB16 & 29.0 & 1.16 & 119 & 59.5 & 47.60 & 1.25 & 41.42 & 1.44 \\
\hline RCA75-DB16 & 32.9 & 1.16 & 125 & 62.5 & 50.74 & 1.23 & 44.15 & 1.42 \\
\hline RCA100-DB16 & 31.9 & 1.16 & 122 & 61.0 & 49.95 & 1.22 & 43.46 & 1.40 \\
\hline RCA0-DB20 & 29.7 & 1.81 & 166.6 & 83.3 & 48.19 & 1.73 & 48.65 & 1.71 \\
\hline RCA25-DB20 & 30.7 & 1.81 & 167.8 & 83.9 & 48.94 & 1.71 & 49.41 & 1.70 \\
\hline RCA50-DB20 & 23.1 & 1.81 & 145 & 72.5 & 42.49 & 1.71 & 42.89 & 1.69 \\
\hline RCA75-DB20 & 34.1 & 1.81 & 175 & 87.5 & 51.55 & 1.70 & 52.04 & 1.68 \\
\hline RCA100-DB20 & 29.5 & 1.81 & 162.4 & 81.2 & 48.01 & 1.69 & 48.47 & 1.67 \\
\hline
\end{tabular}

Recently, ACI 318-19 shear provisions have improved equations to calculate the shear strength of reinforced concrete beams. For beams with shear reinforcement less than the minimum requirement $\left(A_{v}<A_{v, \text { min }}\right)$, the shear equation is:

$$
V_{c}=0.66 \lambda_{s}\left(\rho_{w}\right)^{1 / 3} \sqrt{f_{c}^{\prime}} b d
$$

where $\rho_{\mathrm{w}}$ is the ratio of the longitudinal reinforcement area $\left(A_{s}\right)$ to $b d$ and $\lambda_{s}$ is the size effect modification factor, defined as:

$$
\lambda_{s}=\sqrt{\frac{2}{1+0.004 d}} \leq 1
$$

The shear strength prediction by ACI 318-19 (i.e., Equation (2)) is listed in Table 5 column (8). Comparisons of shear strength ratio $V_{\text {test }} / V_{c}$ from ACI 318-14 and ACI 318-19 are also shown in column (7) and (9) of Table 5, respectively. It is shown that $V_{\text {test }} / V_{c}$ in column (7) of Table 5 ranged from 1.22 for the $100 \%$ RAC beam to 1.29 for the NAC beam with $\rho_{\mathrm{w}}=1.16 \%$. For the beams with $\rho_{\mathrm{w}}=1.81 \%, V_{\text {test }} / V_{c}$ were 1.73 for the NAC beam and 1.69 for the $100 \%$ RAC beam, correspondingly. Figure 7 compares the shear strength from the tests $\left(V_{\text {test }}\right)$ with $V_{c}$ predicted by the ACI 318-14 simplified equation and the ACI 318-19 new shear equation. The shear strength of all tested specimens was higher than the $\mathrm{ACI} 318$ shear prediction. From the graph, it is clear that the $V_{c}$ predicted by ACI 318-19 is more conservative than ACI 318-14 for $\rho_{\mathrm{w}}=1.16 \%$ (DB16 series). However, for $\rho_{\mathrm{W}}=1.81 \%$ (DB20 series), the ACI 318-19 shear strength is slightly higher than that given by ACI 318-14. It is also evident that the shear equation in both ACI 318-14 and ACI 318-19 provisions conservatively estimated the shear strength of RAC beams. Furthermore, these values of $V_{\text {test }} / V_{c}$ shown in the column (7) and (9) in Table 5 indicate a slightly higher margin of safety for NAC over RAC beams.

\subsection{Effect of Longitudinal Reinforcement}

The previous ACI 318 simplified shear equation (Equation (1)) does not consider the effect of longitudinal reinforcement ratio in the shear strength prediction. However, this shortcoming has been improved in ACI 318-19 by introducing $\rho_{\mathrm{w}}$ in the shear expression, as indicated in Equation (2). The difference between normalized shear stress predicted by ACI 318-14 and ACI 318-19 shear provisions at different longitudinal reinforcement ratios 
is plotted in Figure 8 . It is evident that for $\rho_{\mathrm{W}}$ higher than $1.8 \%$, the shear prediction by ACI 318-14 is lower. However, for low $\rho_{\mathrm{w}}, \mathrm{ACI} 318-19$ yields more conservative predictions. The test results from this study showed higher normalized shear stresses for all tested beams compared to both shear equations.

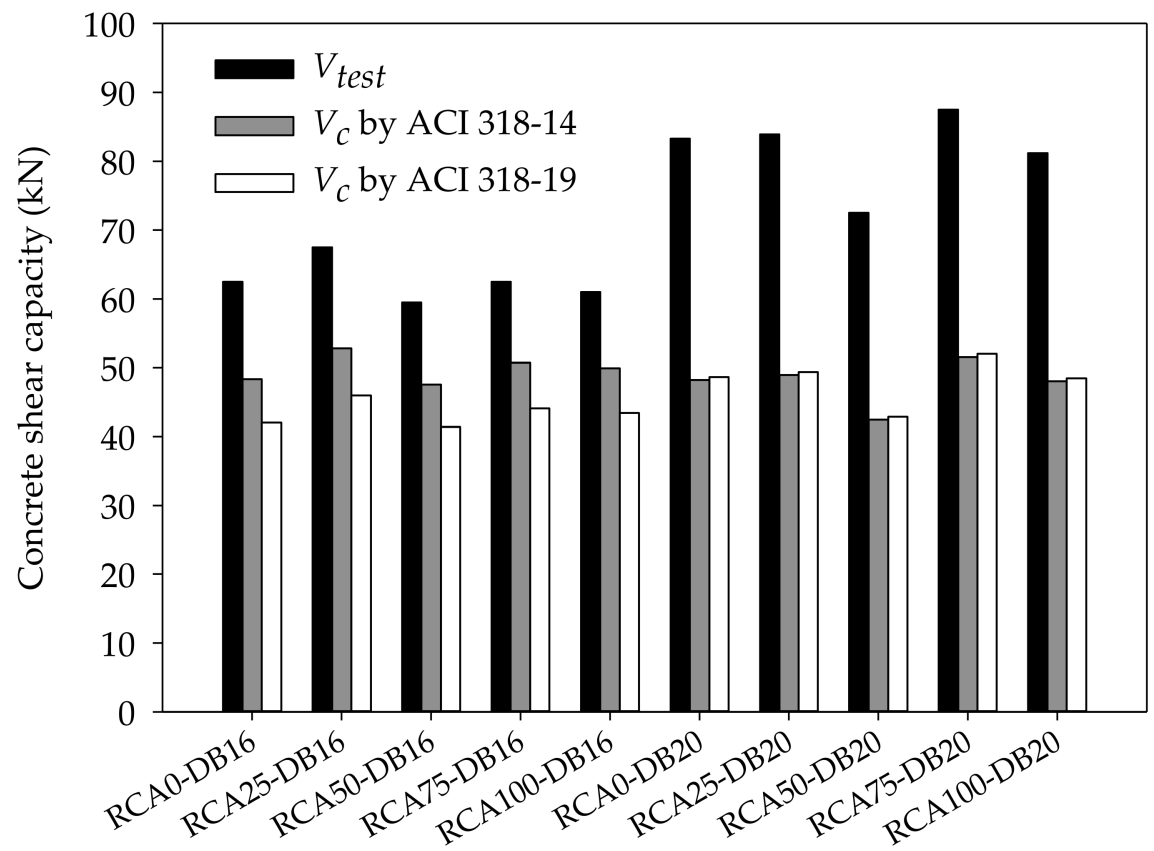

Figure 7. Comparisons of $V_{\text {test }}$ with $V_{c}$ from ACI 318-14 and ACI 318-19 predictions.

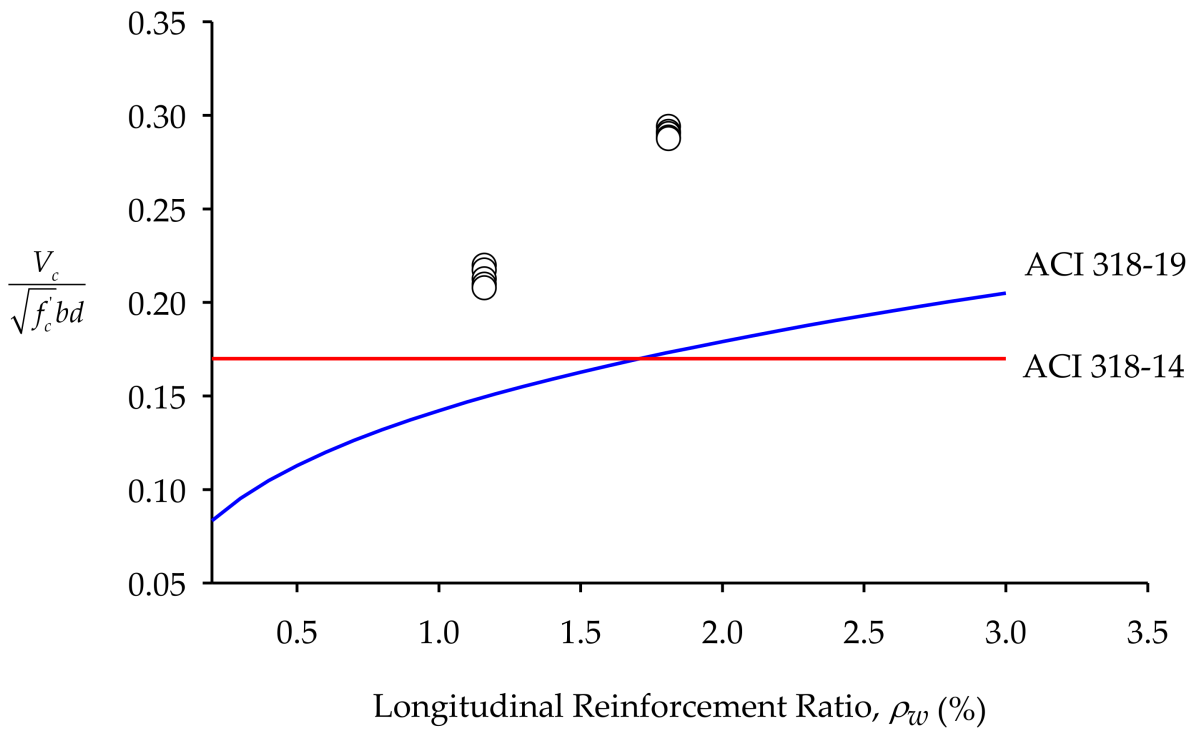

Figure 8. Comparisons of the normalized shear stress from experiments, ACI 318-14, and ACI 318-19.

\subsection{Effect of RCA Replacement Ratio}

Figure 9 compares $V_{\text {test }} / V_{c}$ predicted by ACI 318-14 and ACI 318-19 for the different RCA replacement percentages and longitudinal reinforcement ratios examined in this study. ACI 318-19 shear provisions consider size effects from the effective depth of beam section, as well as the longitudinal reinforcement ratio $\left(\rho_{\mathrm{w}}\right)$. For beams with $\rho_{\mathrm{w}}=1.16 \%$ (3DB16), $V_{c}$ from ACI 318-19 was lower than ACI 318-14. For the beams with $\rho_{\mathrm{w}}=1.81 \%$, $V_{c}$ from both ACI 318-14 and ACI 318-19 were quite similar. However, higher $V_{c}$ was expected from ACI 318-19 shear provisions when $\rho_{\mathrm{w}}$ was greater than 1.8, as discussed in 
the previous section. The decreasing trends in $V_{\text {test }} / V_{c}$ were observed when the amount of RCA increased, particularly in cases of lower $\rho_{\mathrm{w}}$ (DB16 series). However, the decrease rate was low where $V_{\text {test }} / V_{c}$ of RCA100 was only $6 \%$, and $2.2 \%$ lower than that of the NAC beams with $\rho_{\mathrm{w}}=1.16 \%$ and $1.81 \%$, respectively.

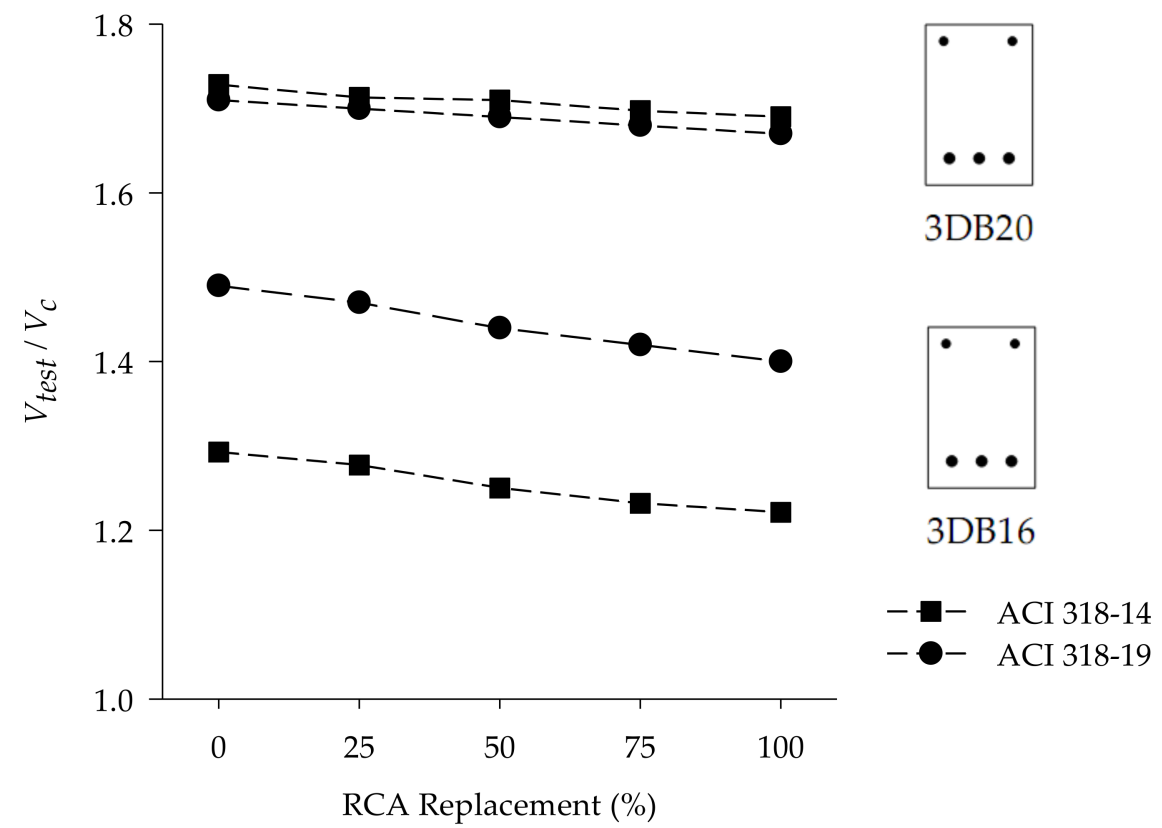

Figure 9. Ratios between ultimate shear from test and concrete shear prediction from ACI318 shear provisions.

\section{Modifications to Code Equation to Allow for the Use of RCA}

\subsection{Proposed RCA Uncertainty Factor to Existing Design Equation}

An experimental shear database was developed to evaluate the applicability of ACI 318-19 to predict the shear strength of RAC beams. The database included a total of 128 results from RAC beams tested by other researchers [22,26-42,46], as well as the beams tested in this study. Details of the 128 beam results are given in Appendix A. The parameters considered in this study were RCA replacement ratio, compressive strength $\left(f^{\prime}\right)$, effective depth $(d)$, shear span-to-effective depth ratio $(a / d)$, and longitudinal reinforcement ratio $\left(\rho_{\mathrm{w}}\right)$. The shear force at failure in all of the tested beams was denoted $V_{\text {test }}$. $V_{c}$ was calculated according to the ACI 318-19 shear provisions, as expressed in Equations (2) and (3).

Figure 10a shows the ratios of tested to calculated shear strength for the RCA replacement percentage. The results indicate that the ACI 318-19 shear equation yielded conservative results when the percentage of RCA was below 75\%, in which only two tested results failed below 1.0. For the beams where RCA completely substituted NCA, eight test results were unconservative.

A comparison between the ratios of shear strength and concrete compressive strength is plotted in Figure 10b. The concrete compressive strength ranged from $20 \mathrm{MPa}$ to $47 \mathrm{MPa}$. Eight out of ten beams that failed below the shear strength predictions had compressive strength below $35 \mathrm{MPa}$.

Figure 10c compares the effects of an effective depth on the $V_{t e s t} / V_{c}$. All unconservative results were from beams with an effective depth below $300 \mathrm{~mm}$. Sixty-nine beams with an effective depth greater than $300 \mathrm{~mm}$ yielded conservative shear predictions.

One of the most important factors influencing the shear strength of reinforced concrete beams is the shear span-to-effective depth ratio $(a / d)$. Figure $10 \mathrm{~d}$ shows the effects of an $a / d$ on the $V_{\text {test }} / V_{c}$. It is obvious that the ratios of shear strength were high for $a / d=1.5$, where an arch action played an important role in providing shear resistance. For slender beams where $a / d$ was at least 2.5 or higher, 10 unconservative results were observed 
out of 109 tests. Figure 10e shows the effect of $\rho_{\mathrm{w}}$ on the ratios of shear strength. The longitudinal reinforcement ratio $\left(\rho_{\mathrm{W}}\right)$ has been recently introduced to ACI 318-19 shear provisions. Before 2019, the shear provisions of ACI 318 offered a simplified equation of shear strength, as shown in Equation (1). Using this equation, other studies on the shear strength of RAC beams with a low longitudinal reinforcement ratio $\left(\rho_{\mathrm{w}}<1 \%\right)$ exhibited 18 unconservative results out of 128 tests [32,36,42], (Figure 11). On the other hand, ACI 318-19 predicted lower shear strength $V_{c}$ for a low longitudinal reinforcement ratio, thus reducing unconservative $V_{\text {test }} / V_{\mathcal{c}}$ to only four tested beams for $\rho_{\mathrm{W}}<1.0 \%$ (Figure 10e).
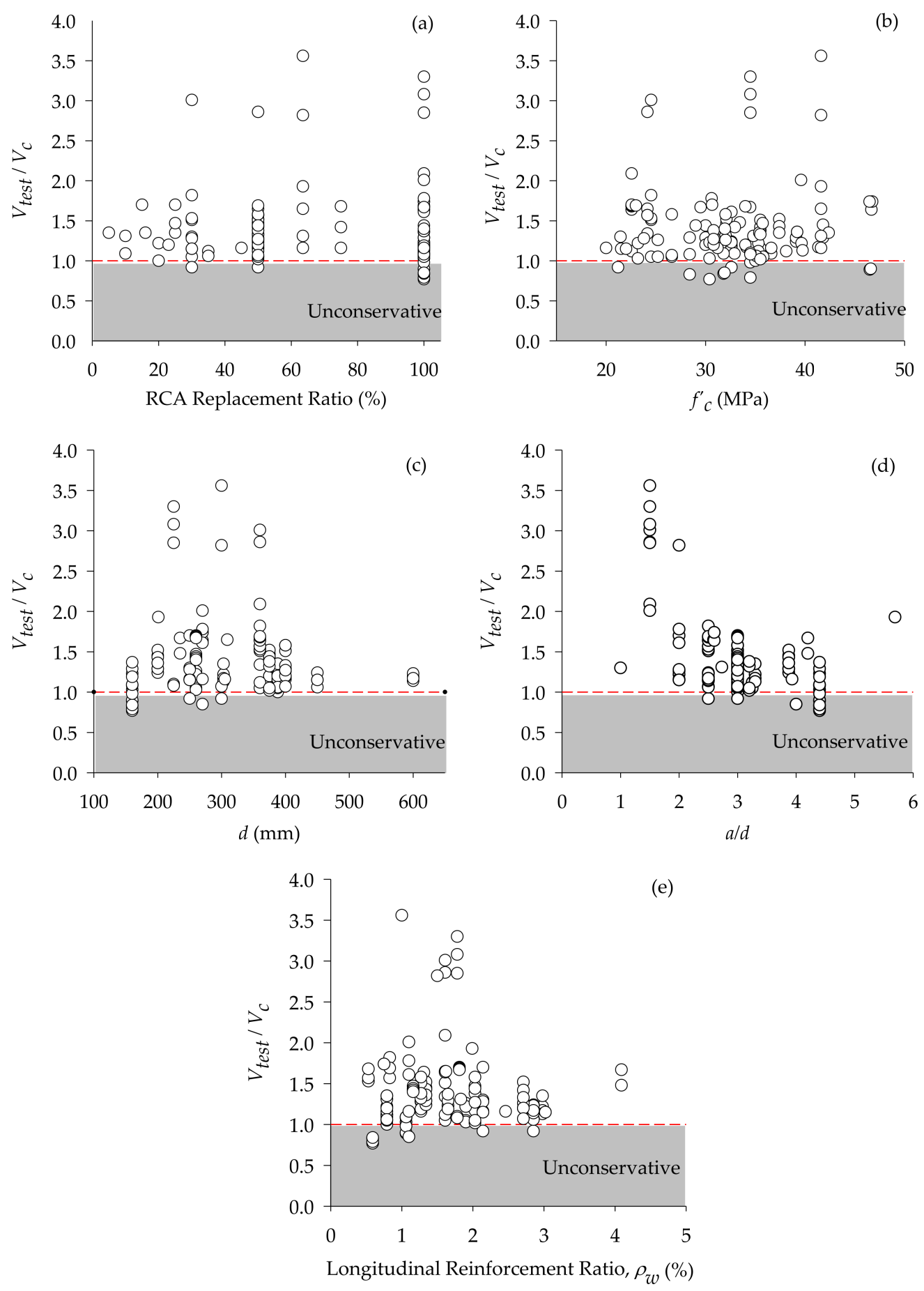

Figure 10. Comparison between $V_{\text {test }} / V_{c}$ using ACI 318-19 shear provisions for different parameters (a) $V_{\text {test }} / V_{c}$ vs. $\%$ RCA (b) $V_{\text {test }} / V_{c}$ vs. $f_{c}^{\prime}$ (c) $V_{\text {test }} / V_{c}$ vs. $d$ (d) $V_{\text {test }} / V_{c}$ vs. $a / d$ (e) $V_{\text {test }} / V_{c}$ vs. $\rho_{\mathrm{w}}$. 


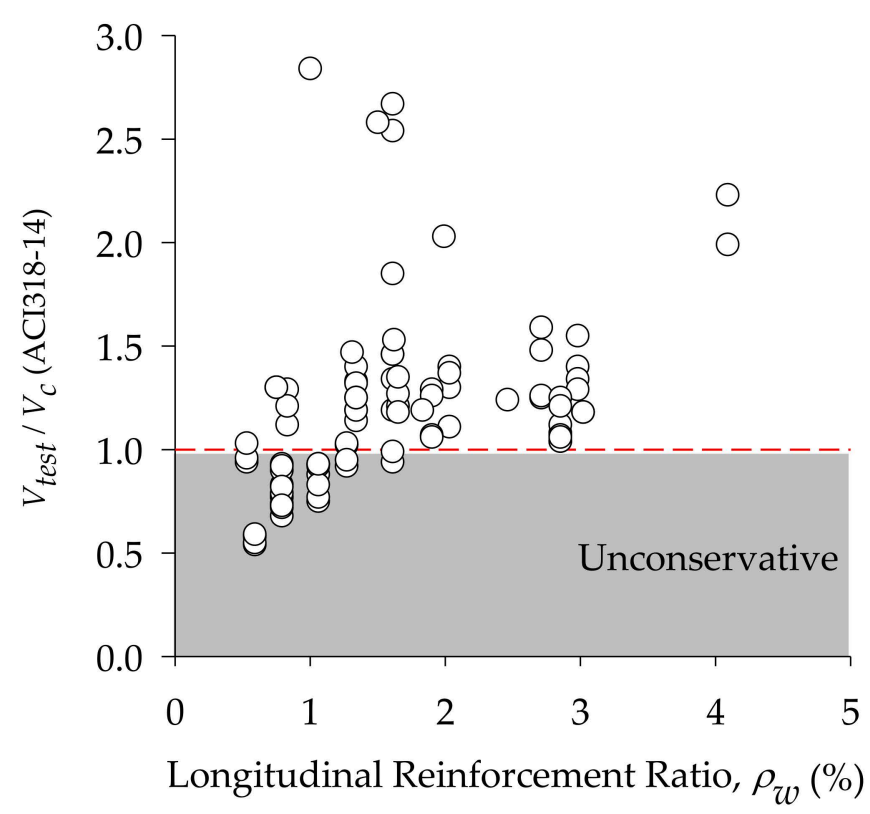

Figure 11. $V_{\text {test }} / V_{c}$ using ACI 318-14 simplified shear equation for different $\rho_{\mathrm{w}}$.

Table 6 shows the average, least conservative value and the coefficient of variation for $V_{\text {test }} / V_{c}$ of beams with $a / d$ greater than 2.5 , in which ACI 318 shear equations are applicable for slender beams. ACI 318-14 yielded some unconservative results, while ACI 318-19 provided a higher average shear strength ratio.

Table 6. Summary of statistical values of shear strength ratio.

\begin{tabular}{cccc}
\hline \multirow{2}{*}{ Code Provision } & \multicolumn{3}{c}{ Ratios of $\boldsymbol{V}_{\text {test }} / \boldsymbol{V}_{\boldsymbol{c}}$} \\
\cline { 2 - 4 } & Average & Least Conservative Value & COV \\
\hline ACI 318-14 & 1.15 & 0.54 & 0.25 \\
ACI 318-19 & 1.28 & 0.77 & 0.30 \\
\hline
\end{tabular}

Rahal and Alrefaei [32] studied the shear strength of RAC beams by analyzing the database of 49 tested beams with $a / d \geq 3$ and compared test results with $v_{\mathcal{C}}$ from ACI 318-14. They found some unconservative results and recommended a reduction factor to account for the detrimental effect of using RCA. Their suggested modification of the simplified ACI 318-14 shear equation was as follows:

$$
v_{c}=0.17 \lambda_{d} \lambda_{R} \sqrt{f_{c}^{\prime}}
$$

where $v_{\mathcal{C}}$ is the shear strength (in $\mathrm{MPa}$ ), $f^{\prime}{ }_{c}$ is the concrete compressive strength (in $\mathrm{MPa}$ ), $\lambda_{d}$ is the reduction factor for lightweight aggregate, and $\lambda_{R}$ is the reduction factor for RCA inclusions. Rahal and Alrefaei [32] recommended $\lambda_{R}=0.8$ in concrete with RCA and 1.0 in concrete with NCA.

In this research study, an additional reduction factor for RCA incorporation, $\beta_{r}$, is proposed, as discussed in the following section.

\subsection{Model Validation and Compared to Existing Test Data}

Table 7 shows the impact of reduction factor $\beta_{r}$ on the number of unconservative results predicted by ACI 318-19 and ACI 318-14 when $a / d$ is greater than 2.5, which is typical for slender beams. It should be noted that unconservative $V_{\text {test }} / V_{c}$ values for the ACI 318-14 simplified shear equation come from tested beams with $\rho_{\mathrm{w}}$ less than $1.0 \%$. 
Table 7. Number of unconservative values of shear strength ratio at different proposed $\beta_{r}$.

\begin{tabular}{ccc}
\hline$\beta_{r}$ & $\begin{array}{c}\text { Number of Unconservative }\left(V_{\text {test }} / V_{c}\right) \\
\text { by Modified ACI 318-19 }\end{array}$ & $\begin{array}{c}\text { Number of Unconservative }\left(V_{\text {test }} / V_{c}\right) \\
\text { by ACI 318-14 }\end{array}$ \\
\hline 0.90 & 6 & 7 \\
0.85 & 4 & 7 \\
0.80 & 2 & 7 \\
0.75 & 0 & 4 \\
\hline
\end{tabular}

Figure 12 compares $V_{\text {test }} / V_{c}$ predicted by the ACI 318-19 shear equations at different RCA levels. Based on the results in the figure, two $\beta_{r}$ were proposed depending on the level of RCA replacement. For RCA replacement levels between $0 \%$ and $50 \%, \beta_{r}=0.9$ was proposed, whereas for RCA between $50 \%$ and $100 \%$ replacement ratio, $\beta_{r}=0.75$ was recommended so that the ACI 318-19 shear equation did not yield unconservative shear strength ratio. Thus, the ACI 318-19 shear strength equation can be modified as follows:

$$
V_{c}=0.66 \lambda_{s} \lambda \beta_{r}\left(\rho_{w}\right)^{1 / 3} \sqrt{f_{c}^{\prime}} b d
$$

where $\rho_{\mathrm{w}}$ is the ratio of longitudinal reinforcement area $\left(A_{s}\right)$ to $b d, \lambda_{s}$ is the size effect modification factor defined in Equation (3), $\lambda$ is the reduction factor for lightweight aggregate, and $\beta_{r}$ is the proposed reduction factor for RCA incorporation: $\beta_{r}=0.75$ for RCA replacement ratios between $50 \%$ and $100 \%$, or otherwise $\beta_{r}=0.9$.

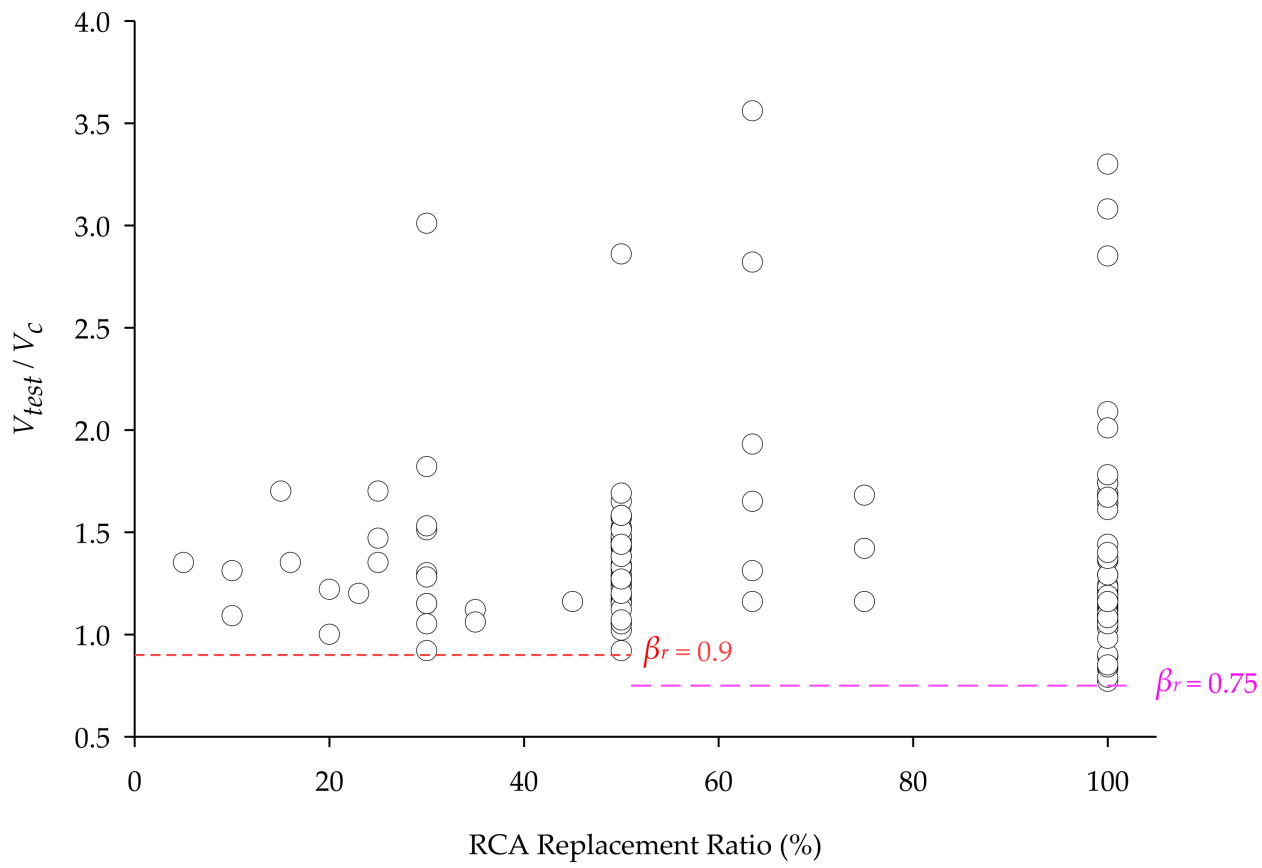

Figure 12. The proposed reduction factor for RCA to shear strength predicted by ACI 318-19 shear equation.

It should be noted that this $\beta_{r}$ reduction factor accounts for the (i) physical variations of RCA, such as replacement ratio, source, density, amount of residual mortar, and physical irregularities, as reported by several researchers [5,14-18], and (ii) lower shear strength of RAC beams compared to NAC beams [30-34]. The detailed results of the shear strength of the beams in the database using Equations (4) and (5) is included in Appendix A. Equations (1), (2), (4) and (5) yield an average $V_{\text {test }} / V_{c}$ equal to $1.27,1.40,1.59$, and 1.72 respectively. It is evident that the highest $V_{\text {test }} / V_{c}$ of 1.72 yields the most conservative predictions for all ranges of RCA replacements when using Equation (5), which includes $\beta_{r}$ proposed in this study. 
Figure 13 shows the ratios between the experimental shear strengths $\left(V_{\text {test }}\right)$ and the proposed shear strength $\left(V_{c}\right)$, as defined in Equation (5). Mean and standard deviation (SD) values are included in the plot. It can be seen that the proposed modified equation yielded most of the shear strength ratios within the range of the mean \pm standard deviation. The proposed shear equation was also conservative $\left(V_{\text {test }} / V_{c}>1\right)$ for all levels of RCA replacement ratios.

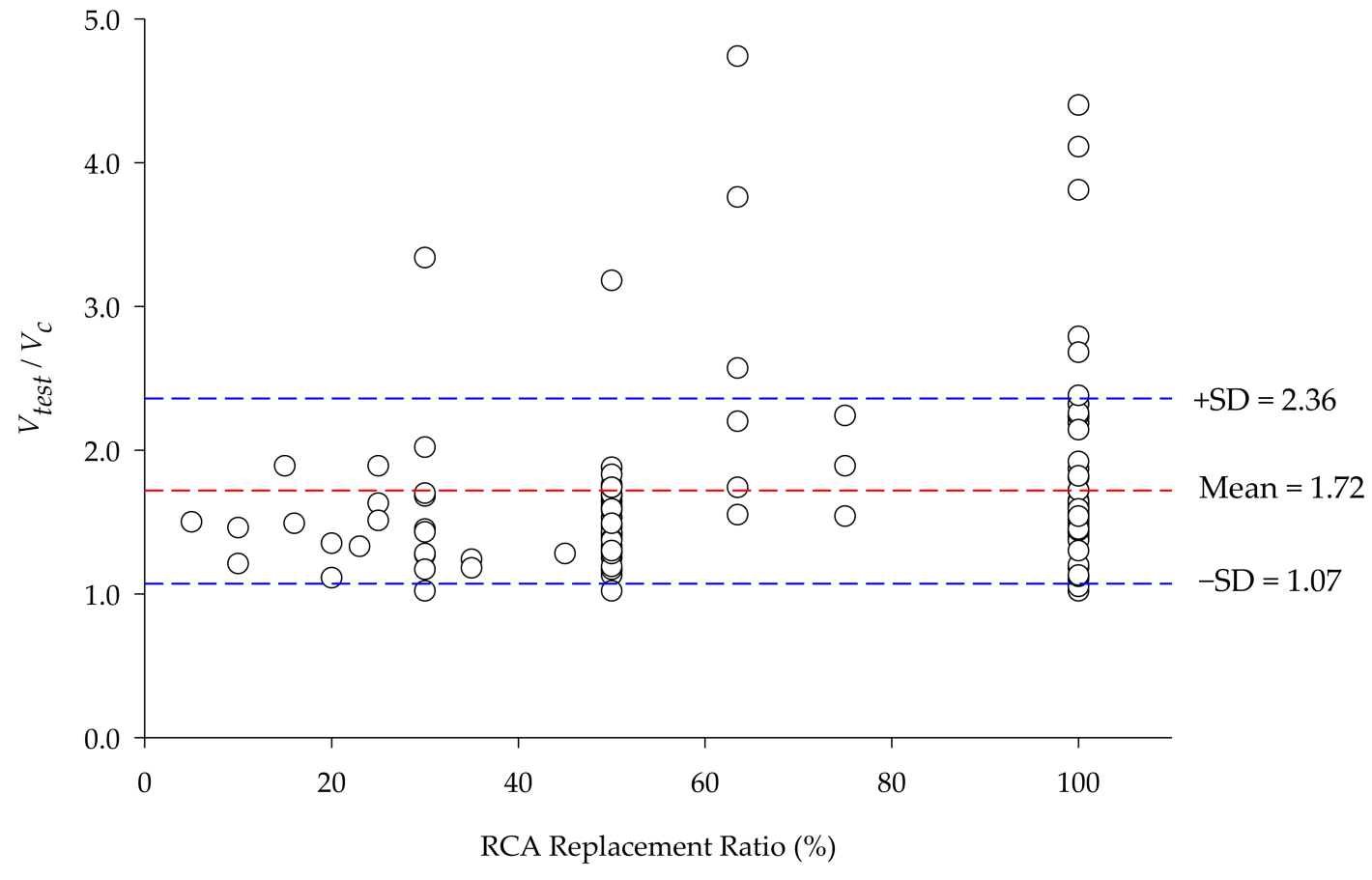

Figure 13. Evaluation of the proposed shear equation.

\subsection{Design Recommendations}

Based on the test results from 128 RAC beams without stirrups found in the existing literature, a reduction factor of $\beta_{r}=0.75$ for RCA replacement ratios between $50 \%$ and $100 \%$ is suggested for the ACI 318-19 shear equation to yield the best results without an unconservative shear strength ratio. A reduction factor of $\beta_{r}=0.9$ is suggested for RCA replacement ratios not greater than $50 \%$. Typical aggregate sizes below $25 \mathrm{~mm}$ are recommended, as the tested beams in the database used RCA sizes smaller than $25 \mathrm{~mm}$. However, the nature of the shear behavior of reinforced concrete beams is complex, and more tests on RAC beams are required to fully validate these design recommendations.

\section{Conclusions and Future Works}

This article investigated experimentally and analytically the shear strength of concrete beams with RCA as coarse aggregate. Different RCA replacements and different amounts of longitudinal reinforcement were used. Predictions of concrete shear strength from the current ACI provisions were evaluated against a database from tests found in the literature. A modification to the current $\mathrm{ACI}$ concrete shear strength equation was proposed for different RCA replacements.

Based on the test results of ten beams and the analysis of the 128 RAC beams from the database, the following conclusions can be drawn:

- For beams with a longitudinal reinforcement ratio of $1.16 \%$, the normalized shear stress of the $100 \%$ RAC beam was $6 \%$ lower than that of the NAC counterpart.

- The normalized shear stress of RAC and NAC beams with a longitudinal reinforcement ratio of $1.81 \%$ had a minimal difference. 
- The shear failure modes of RAC and NAC beams were similar. However, the crack inclination angles of NAC beams were slightly higher.

- The current ACI 318-19 shear equation conservatively estimates the shear strength of RAC beams when the replacement percentage is less than $75 \%$.

- For a longitudinal reinforcement ratio less than $1.8 \%$, the ACI 318-19 shear equation yielded lower shear strengths $\left(V_{c}\right)$ than the ACI 318-14 simplified equation, thus increasing the safety factor of shear stress ratios found in previous tests in the literature.

- A reduction factor of 0.75 for RCA between $50 \%$ and $100 \%$ is proposed to the current ACI code provision to account for the physical variations of RCA, such as percentage replacement, source, density, percentage of residual mortar, and physical irregularity.

- The modified ACI equation for predicting the concrete shear strength of RAC beams was calibrated using eight test data carried out by the authors, and then further verified and calibrated against 120 test data from the literature. The use of the modified $\mathrm{ACI}$ equation as a design recommendation for predicting the concrete shear strength of RAC beams gives conservative predictions for all levels of RCA up to $100 \%$ replacement.

It is noted that the design recommendations include a reduction factor to the modified version of ACI code provisions, which was empirically derived based on the 128 tests available in the literature. However, more shear tests on RAC members are required in order to fully consider the physical variations of recycled concrete to be used as coarse aggregate replacement.

Author Contributions: Conceptualization, M.S. and S.L. (Satjapan Leelatanon); methodology, M.S. and S.L. (Satjapan Leelatanon); validation, S.L. (Suchart Limkatanyu) and R.G.; formal analysis, M.S. and T.I.; investigation, S.L. (Satjapan Leelatanon), R.G., S.L. (Suchart Limkatanyu) and T.I.; resources, S.L. (Suchart Limkatanyu); writing—original draft preparation, M.S., S.L. (Satjapan Leelatanon), T.I.; writing-review and editing, M.S., T.I., S.L. (Satjapan Leelatanon), S.L. (Suchart Limkatanyu) and R.G.; supervision, S.L. (Suchart Limkatanyu), R.G. and T.I. All authors have read and agreed to the published version of the manuscript.

Funding: This research was funded by a Walailak University research grant (contract no. WU63217). The authors acknowledge the partially financial support by the National Research Council of Thailand (NRCT5-RSA63019-04) and TRF Senior Research Scholar (RTA6280012). This research was partially supported by the new strategic research (P2P) project, Walailak University, Thailand. This project was also supported by the Capacity Enhancement and Driving Strategies for Bilateral and Multilateral Cooperation for 2021 (Thailand and United Kingdom).

Institutional Review Board Statement: Not applicable.

Informed Consent Statement: Not applicable.

Data Availability Statement: Not applicable.

Acknowledgments: The authors thankfully acknowledge Sanhanut Sombatthong, Thiraphongsa Thamsiriphaiboon, Phongsakorn Srisiri, Pattarapol Meeprapai, Jenwit Chookaew, and Pattarawan Thavorn for their contribution during the experimental program.

Conflicts of Interest: The authors declare no conflict of interest. 


\section{Appendix A}

Table A1. Comparison of concrete shear strength of RCA in concrete beams without shear reinforcement by current ACI codes and modified equations.

\begin{tabular}{|c|c|c|c|c|c|c|c|c|c|c|c|c|}
\hline Reference & ID & $\%$ RCA & $\begin{array}{c}f_{c}^{\prime} \\
(\mathrm{MPa})\end{array}$ & $\begin{array}{c}b \\
(\mathrm{~mm})\end{array}$ & $\begin{array}{c}d \\
(\mathrm{~mm})\end{array}$ & ald & $\begin{array}{l}\rho_{\mathrm{w}} \\
(\%)\end{array}$ & $\begin{array}{l}V_{\text {test }} \\
(\mathbf{k N})\end{array}$ & Equation (1) & Equation (2) & Equation (4) & Equation (5) \\
\hline \multirow{8}{*}{ This study (2021) } & 1 & 25 & 35.7 & 200 & 260 & 3.08 & 1.16 & 67.50 & 52.9 & 46.0 & 42.3 & 41.4 \\
\hline & 2 & 50 & 29.0 & 200 & 260 & 3.08 & 1.16 & 59.50 & 47.6 & 41.4 & 38.1 & 37.3 \\
\hline & 3 & 75 & 32.9 & 200 & 260 & 3.08 & 1.16 & 62.50 & 50.7 & 44.2 & 40.6 & 33.1 \\
\hline & 4 & 100 & 31.9 & 200 & 260 & 3.08 & 1.16 & 61.00 & 50.0 & 43.5 & 40.0 & 32.6 \\
\hline & 5 & 25 & 30.7 & 200 & 260 & 3.08 & 1.81 & 83.85 & 48.9 & 49.4 & 39.2 & 44.5 \\
\hline & 6 & 50 & 23.0 & 200 & 260 & 3.08 & 1.81 & 72.50 & 42.4 & 42.8 & 33.9 & 38.5 \\
\hline & 7 & 75 & 34.0 & 200 & 260 & 3.08 & 1.81 & 87.50 & 51.6 & 52.0 & 41.2 & 39.0 \\
\hline & 8 & 100 & 29.5 & 200 & 260 & 3.08 & 1.81 & 81.15 & 48.0 & 48.5 & 38.4 & 36.3 \\
\hline \multirow{4}{*}{ Wardeh and Ghorbel (2019) [35] } & 10 & 100 & 34.5 & 200 & 225 & 1.5 & 1.78 & 150.30 & 44.9 & 45.6 & 35.9 & 34.2 \\
\hline & 11 & 100 & 34.5 & 200 & 225 & 1.5 & 1.78 & 140.40 & 44.9 & 45.6 & 35.9 & 34.2 \\
\hline & 12 & 100 & 34.5 & 200 & 225 & 3 & 1.78 & 50.20 & 44.9 & 45.6 & 35.9 & 34.2 \\
\hline & 13 & 100 & 34.5 & 200 & 225 & 3 & 1.78 & 49.00 & 44.9 & 45.6 & 35.9 & 34.2 \\
\hline \multirow{3}{*}{ Pradhan et al. (2018) [34] } & 14 & 100 & 46.7 & 200 & 270 & 2.6 & 1.31 & 92.28 & 62.7 & 56.3 & 50.2 & 42.2 \\
\hline & 15 & 100 & 46.8 & 200 & 270 & 2.6 & 0.75 & 81.29 & 62.8 & 46.8 & 50.2 & 35.1 \\
\hline & 16 & 100 & 46.5 & 200 & 270 & 2.6 & 0.75 & 81.10 & 62.6 & 46.6 & 50.1 & 35.0 \\
\hline \multirow{6}{*}{ Etman et al. (2018) [33] } & 17 & 15 & 22.6 & 150 & 250 & 2 & 2.14 & 55.50 & 30.3 & 32.6 & 24.2 & 29.4 \\
\hline & 18 & 30 & 21.5 & 150 & 250 & 2 & 2.14 & 36.50 & 29.6 & 31.9 & 23.7 & 28.7 \\
\hline & 19 & 45 & 20.0 & 150 & 250 & 2 & 2.14 & 35.50 & 28.5 & 30.7 & 22.8 & 27.7 \\
\hline & 21 & 30 & 21.2 & 150 & 250 & 3 & 2.14 & 29.00 & 29.4 & 31.6 & 23.5 & 28.5 \\
\hline & 22 & 30 & 23.8 & 150 & 250 & 2 & 2.14 & 43.00 & 31.1 & 33.5 & 24.9 & 30.2 \\
\hline & 23 & 30 & 22.0 & 150 & 250 & 2 & 2.14 & 37.00 & 29.9 & 32.2 & 23.9 & 29.0 \\
\hline \multirow{2}{*}{ Ignjatović et al. (2017) [29] } & 24 & 50 & 33.4 & 200 & 235 & 4.2 & 4.09 & 91.75 & 46.2 & 61.8 & 37.0 & 55.6 \\
\hline & 25 & 100 & 34.5 & 200 & 235 & 4.2 & 4.09 & 104.75 & 46.9 & 62.8 & 37.5 & 47.1 \\
\hline \multirow{12}{*}{ Rahal and Alrefaei (2017) [32] } & 26 & 10 & 36.6 & 150 & 388 & 3 & 0.79 & 44.50 & 59.9 & 41.0 & 47.9 & 36.9 \\
\hline & 27 & 20 & 35.0 & 150 & 388 & 3 & 0.79 & 40.05 & 58.5 & 40.1 & 46.8 & 36.1 \\
\hline & 28 & 20 & 35.3 & 150 & 388 & 3 & 0.79 & 48.90 & 58.8 & 40.2 & 47.0 & 36.2 \\
\hline & 29 & 35 & 35.3 & 150 & 388 & 3 & 0.79 & 45.05 & 58.8 & 40.2 & 47.0 & 36.2 \\
\hline & 30 & 50 & 38.1 & 150 & 388 & 3 & 0.79 & 46.95 & 61.1 & 41.8 & 48.9 & 37.6 \\
\hline & 31 & 75 & 36.6 & 150 & 388 & 3 & 0.79 & 47.40 & 59.9 & 41.0 & 47.9 & 30.7 \\
\hline & 32 & 100 & 35.8 & 150 & 388 & 3 & 0.79 & 42.50 & 59.2 & 40.5 & 47.4 & 30.4 \\
\hline & 33 & 5 & 37.4 & 150 & 388 & 3 & 0.79 & 56.00 & 60.5 & 41.4 & 48.4 & 37.3 \\
\hline & 34 & 10 & 34.8 & 150 & 388 & 3 & 0.79 & 52.50 & 58.4 & 40.0 & 46.7 & 36.0 \\
\hline & 35 & 16 & 35.4 & 150 & 388 & 3 & 0.79 & 54.20 & 58.9 & 40.3 & 47.1 & 36.3 \\
\hline & 36 & 23 & 34.0 & 150 & 388 & 3 & 0.79 & 47.25 & 57.7 & 39.5 & 46.2 & 35.5 \\
\hline & 37 & 35 & 35.1 & 150 & 388 & 3 & 0.79 & 42.50 & 58.6 & 40.1 & 46.9 & 36.1 \\
\hline
\end{tabular}


Table A1. Cont.

\begin{tabular}{|c|c|c|c|c|c|c|c|c|c|c|c|c|}
\hline Reference & ID & $\%$ RCA & $\begin{array}{c}f_{c}^{\prime} \\
\text { (MPa) }\end{array}$ & $\begin{array}{c}b \\
(\mathrm{~mm})\end{array}$ & $\begin{array}{c}d \\
(\mathrm{~mm})\end{array}$ & ald & $\begin{array}{l}\rho_{\mathrm{w}} \\
(\%)\end{array}$ & $\begin{array}{l}V_{\text {test }} \\
(\mathbf{k N})\end{array}$ & Equation (1) & Equation (2) & Equation (4) & Equation (5) \\
\hline \multirow{4}{*}{ Katkhuda and Shatarat (2016) [39] } & 38 & 50 & 25.2 & 206 & 260 & 2 & 1.90 & 58.94 & 45.7 & 46.9 & 36.6 & 42.2 \\
\hline & 39 & 50 & 25.2 & 206 & 260 & 3 & 1.90 & 49.07 & 45.7 & 46.9 & 36.6 & 42.2 \\
\hline & 40 & 100 & 23.2 & 206 & 260 & 2 & 1.90 & 55.04 & 43.9 & 45.0 & 35.1 & 33.7 \\
\hline & 41 & 100 & 23.2 & 206 & 260 & 3 & 1.90 & 46.45 & 43.9 & 45.0 & 35.1 & 33.7 \\
\hline \multirow{11}{*}{ Sadati et al. (2016) [38] } & 42 & 50 & 32.0 & 305 & 375 & 3.2 & 1.27 & 117.40 & 110.0 & 89.1 & 88.0 & 80.2 \\
\hline & 43 & 50 & 35.5 & 305 & 375 & 3.2 & 2.03 & 111.60 & 115.9 & 109.7 & 92.7 & 98.8 \\
\hline & 44 & 50 & 32.0 & 305 & 400 & 3 & 2.71 & 151.20 & 117.3 & 120.0 & 93.9 & 108.0 \\
\hline & 45 & 50 & 35.5 & 305 & 400 & 3 & 1.27 & 148.60 & 123.6 & 98.2 & 98.9 & 88.4 \\
\hline & 47 & 50 & 35.5 & 305 & 400 & 3 & 2.71 & 168.60 & 123.6 & 126.4 & 98.9 & 113.8 \\
\hline & 48 & 50 & 30.8 & 305 & 375 & 3.2 & 1.27 & 120.50 & 107.9 & 87.4 & 86.3 & 78.7 \\
\hline & 49 & 50 & 26.6 & 305 & 375 & 3.2 & 2.03 & 99.90 & 100.3 & 95.0 & 80.2 & 85.5 \\
\hline & 50 & 50 & 30.8 & 305 & 400 & 3 & 2.71 & 140.80 & 115.1 & 117.7 & 92.1 & 105.9 \\
\hline & 51 & 50 & 26.6 & 305 & 400 & 3 & 1.27 & 134.60 & 107.0 & 85.0 & 85.6 & 76.5 \\
\hline & 52 & 50 & 30.8 & 305 & 400 & 3 & 2.03 & 136.30 & 115.1 & 106.9 & 92.1 & 96.2 \\
\hline & 53 & 50 & 26.6 & 305 & 400 & 3 & 2.71 & 116.80 & 107.0 & 109.4 & 85.6 & 98.5 \\
\hline \multirow{11}{*}{ Arezoumandi (2014 \& 2015) [30,31] } & 54 & 50 & 32.1 & 300 & 400 & 3 & 1.27 & 117.50 & 115.6 & 91.8 & 92.5 & 82.6 \\
\hline & 55 & 50 & 32.1 & 300 & 375 & 3 & 2.03 & 151.30 & 108.4 & 102.6 & 86.7 & 92.4 \\
\hline & 56 & 50 & 32.1 & 300 & 375 & 3 & 2.71 & 171.80 & 108.4 & 113.0 & 86.7 & 101.7 \\
\hline & 58 & 50 & 35.5 & 300 & 375 & 3 & 2.03 & 148.60 & 114.0 & 107.9 & 91.2 & 97.1 \\
\hline & 59 & 50 & 35.5 & 300 & 375 & 3 & 2.71 & 168.70 & 114.0 & 118.9 & 91.2 & 107.0 \\
\hline & 60 & 100 & 30.0 & 300 & 400 & 3 & 1.27 & 114.80 & 111.7 & 88.8 & 89.4 & 66.6 \\
\hline & 61 & 100 & 30.0 & 300 & 375 & 3 & 2.03 & 143.20 & 104.8 & 99.2 & 83.8 & 74.4 \\
\hline & 62 & 100 & 30.0 & 300 & 375 & 3 & 2.71 & 131.40 & 104.8 & 109.3 & 83.8 & 81.9 \\
\hline & 63 & 100 & 34.1 & 300 & 400 & 3 & 1.27 & 113.00 & 119.1 & 94.6 & 95.3 & 71.0 \\
\hline & 64 & 100 & 34.1 & 300 & 375 & 3 & 2.03 & 124.10 & 111.7 & 105.8 & 89.3 & 79.3 \\
\hline & 65 & 100 & 34.1 & 300 & 375 & 3 & 2.71 & 140.30 & 111.7 & 116.5 & 89.3 & 87.4 \\
\hline \multirow{8}{*}{ Knaack and Kurama (2014) [28] } & 66 & 50 & 41.8 & 150 & 200 & 3.875 & 1.34 & 44.00 & 33.0 & 30.4 & 26.4 & 27.4 \\
\hline & 67 & 50 & 41.8 & 150 & 200 & 3.875 & 1.34 & 39.10 & 33.0 & 30.4 & 26.4 & 27.4 \\
\hline & 68 & 50 & 37.4 & 150 & 200 & 3.875 & 1.34 & 43.70 & 31.2 & 28.8 & 25.0 & 25.9 \\
\hline & 69 & 50 & 37.4 & 150 & 200 & 3.875 & 1.34 & 41.20 & 31.2 & 28.8 & 25.0 & 25.9 \\
\hline & 70 & 100 & 39.1 & 150 & 200 & 3.875 & 1.34 & 36.40 & 31.9 & 29.4 & 25.5 & 22.1 \\
\hline & 71 & 100 & 39.1 & 150 & 200 & 3.875 & 1.34 & 38.00 & 31.9 & 29.4 & 25.5 & 22.1 \\
\hline & 72 & 100 & 39.2 & 150 & 200 & 3.875 & 1.34 & 39.90 & 31.9 & 29.4 & 25.5 & 22.1 \\
\hline & 73 & 100 & 39.2 & 150 & 200 & 3.875 & 1.34 & 39.90 & 31.9 & 29.4 & 25.5 & 22.1 \\
\hline
\end{tabular}


Table A1. Cont.

\begin{tabular}{|c|c|c|c|c|c|c|c|c|c|c|c|c|}
\hline Reference & ID & $\%$ RCA & $\begin{array}{l}f^{\prime}{ }_{c} \\
(\mathrm{MPa})\end{array}$ & $\begin{array}{c}b \\
(\mathrm{~mm})\end{array}$ & $\begin{array}{c}d \\
(\mathrm{~mm})\end{array}$ & $a / d$ & $\begin{array}{l}\rho_{\mathrm{w}} \\
(\%)\end{array}$ & $\begin{array}{l}V_{\text {test }} \\
(\mathbf{k N})\end{array}$ & Equation (1) & Equation (2) & Equation (4) & Equation (5) \\
\hline \multirow{9}{*}{ Kim et al. (2013) [40] } & 74 & 50 & 32.6 & 200 & 300 & 2.5 & 2.85 & 60.60 & 58.2 & 65.9 & 46.6 & 59.3 \\
\hline & 75 & 50 & 32.6 & 200 & 450 & 2.5 & 2.85 & 108.90 & 87.4 & 87.6 & 69.9 & 78.8 \\
\hline & 76 & 50 & 32.6 & 200 & 600 & 2.5 & 2.85 & 126.10 & 116.5 & 105.9 & 93.2 & 95.3 \\
\hline & 77 & 50 & 32.6 & 300 & 450 & 2.5 & 3.02 & 154.20 & 131.0 & 133.9 & 104.8 & 120.5 \\
\hline & 78 & 50 & 32.6 & 400 & 600 & 2.5 & 2.85 & 261.50 & 233.0 & 211.9 & 186.4 & 190.7 \\
\hline & 79 & 100 & 34.9 & 200 & 300 & 2.5 & 2.85 & 72.90 & 60.3 & 68.1 & 48.2 & 51.1 \\
\hline & 80 & 100 & 34.9 & 200 & 450 & 2.5 & 2.85 & 96.40 & 90.4 & 90.6 & 72.3 & 67.9 \\
\hline & 81 & 100 & 34.9 & 200 & 600 & 2.5 & 2.85 & 125.10 & 120.5 & 109.6 & 96.4 & 82.2 \\
\hline & 83 & 100 & 34.9 & 400 & 600 & 2.5 & 2.85 & 256.60 & 241.0 & 219.2 & 192.8 & 164.4 \\
\hline \multirow{6}{*}{ Fathifazl et al. (2011) [22] } & 84 & 63.5 & 41.6 & 200 & 300 & 1.5 & 1.00 & 186.70 & 65.8 & 52.5 & 52.6 & 39.4 \\
\hline & 85 & 63.5 & 41.6 & 200 & 300 & 2 & 1.50 & 169.50 & 65.8 & 60.1 & 52.6 & 45.0 \\
\hline & 86 & 63.5 & 41.6 & 200 & 309 & 2.59 & 1.62 & 103.90 & 67.8 & 63.0 & 54.2 & 47.2 \\
\hline & 87 & 63.5 & 41.6 & 200 & 201 & 5.69 & 1.99 & 89.30 & 44.1 & 46.4 & 35.3 & 34.8 \\
\hline & 88 & 63.5 & 41.6 & 200 & 305 & 3.93 & 2.46 & 83.20 & 66.9 & 71.7 & 53.5 & 53.8 \\
\hline & 89 & 63.5 & 41.6 & 200 & 381 & 2.73 & 1.83 & 99.50 & 83.6 & 76.1 & 66.8 & 57.1 \\
\hline \multirow{14}{*}{ Choi et al. (2010) [41] } & 90 & 30 & 24.5 & 200 & 360 & 1.5 & 1.61 & 161.70 & 60.6 & 53.8 & 48.5 & 48.4 \\
\hline & 91 & 30 & 24.5 & 200 & 360 & 2.5 & 1.61 & 81.34 & 60.6 & 53.8 & 48.5 & 48.4 \\
\hline & 92 & 30 & 24.5 & 200 & 360 & 3.25 & 1.61 & 56.70 & 60.6 & 53.8 & 48.5 & 48.4 \\
\hline & 94 & 30 & 24.5 & 200 & 360 & 2.5 & 0.83 & 78.40 & 60.6 & 43.1 & 48.5 & 38.8 \\
\hline & 95 & 50 & 24.2 & 200 & 360 & 1.5 & 1.61 & 152.88 & 60.2 & 53.4 & 48.1 & 48.1 \\
\hline & 96 & 50 & 24.2 & 200 & 360 & 2.5 & 1.61 & 87.90 & 60.2 & 53.4 & 48.1 & 48.1 \\
\hline & 97 & 50 & 24.2 & 200 & 360 & 3.25 & 1.61 & 71.54 & 60.2 & 53.4 & 48.1 & 48.1 \\
\hline & 98 & 50 & 24.2 & 200 & 360 & 2.5 & 0.53 & 57.82 & 60.2 & 36.9 & 48.1 & 33.2 \\
\hline & 99 & 50 & 24.2 & 200 & 360 & 2.5 & 0.83 & 67.13 & 60.2 & 42.8 & 48.1 & 38.5 \\
\hline & 100 & 100 & 22.6 & 200 & 360 & 1.5 & 1.61 & 107.80 & 58.1 & 51.6 & 46.5 & 38.7 \\
\hline & 101 & 100 & 22.6 & 200 & 360 & 2.5 & 1.61 & 84.77 & 58.1 & 51.6 & 46.5 & 38.7 \\
\hline & 102 & 100 & 22.6 & 200 & 360 & 3.25 & 1.61 & 57.77 & 58.1 & 51.6 & 46.5 & 38.7 \\
\hline & 103 & 100 & 22.6 & 200 & 360 & 2.5 & 0.53 & 59.78 & 58.1 & 35.6 & 46.5 & 26.7 \\
\hline & 104 & 100 & 22.6 & 200 & 360 & 2.5 & 0.83 & 70.07 & 58.1 & 41.4 & 46.5 & 31.0 \\
\hline $\begin{array}{l}\text { González-Fonteboa and } \\
\text { Martínez-Abella (2007) [27] }\end{array}$ & 105 & 100 & 39.7 & 200 & 303 & 3.3 & 2.98 & 90.64 & 64.9 & 74.2 & 51.9 & 55.7 \\
\hline \multirow{3}{*}{ Etxeberria et al. (2007) [26] } & 106 & 25 & 42.4 & 200 & 303 & 3.3 & 2.98 & 104.00 & 67.1 & 76.8 & 53.7 & 69.1 \\
\hline & 107 & 50 & 41.3 & 200 & 303 & 3.3 & 2.98 & 89.00 & 66.2 & 75.8 & 53.0 & 68.2 \\
\hline & 108 & 100 & 39.8 & 200 & 303 & 3.3 & 2.98 & 84.00 & 65.0 & 74.3 & 52.0 & 55.8 \\
\hline
\end{tabular}


Table A1. Cont.

\begin{tabular}{|c|c|c|c|c|c|c|c|c|c|c|c|c|}
\hline Reference & ID & $\%$ RCA & $\begin{array}{c}f_{c}^{\prime} \\
(\mathrm{MPa})\end{array}$ & $\begin{array}{c}b \\
(\mathrm{~mm})\end{array}$ & $\begin{array}{c}d \\
(\mathrm{~mm})\end{array}$ & $a / d$ & $\begin{array}{l}\rho_{\mathrm{w}} \\
(\%)\end{array}$ & $\begin{array}{l}V_{\text {test }} \\
(\mathbf{k N})\end{array}$ & Equation (1) & Equation (2) & Equation (4) & Equation (5) \\
\hline \multirow{15}{*}{ Sato et al. (2007) [42] } & 109 & 100 & 46.5 & 150 & 160 & 4.4 & 1.06 & 21.00 & 27.8 & 23.7 & 22.3 & 17.8 \\
\hline & 110 & 100 & 32.9 & 150 & 160 & 4.4 & 1.06 & 21.70 & 23.4 & 20.0 & 18.7 & 15.0 \\
\hline & 111 & 100 & 46.6 & 150 & 160 & 4.4 & 1.06 & 21.40 & 27.9 & 23.8 & 22.3 & 17.8 \\
\hline & 112 & 100 & 30.4 & 150 & 160 & 4.4 & 0.59 & 12.10 & 22.5 & 15.8 & 18.0 & 11.8 \\
\hline & 113 & 100 & 28.4 & 150 & 160 & 4.4 & 0.59 & 12.60 & 21.7 & 15.3 & 17.4 & 11.4 \\
\hline & 114 & 100 & 34.5 & 150 & 160 & 4.4 & 0.59 & 13.20 & 24.0 & 16.8 & 19.2 & 12.6 \\
\hline & 115 & 100 & 31.8 & 150 & 160 & 4.4 & 0.59 & 13.50 & 23.0 & 16.1 & 18.4 & 12.1 \\
\hline & 116 & 100 & 30.4 & 150 & 160 & 4.4 & 1.06 & 19.70 & 22.5 & 19.2 & 18.0 & 14.4 \\
\hline & 117 & 100 & 28.4 & 150 & 160 & 4.4 & 1.06 & 20.00 & 21.7 & 18.5 & 17.4 & 13.9 \\
\hline & 118 & 100 & 34.5 & 150 & 160 & 4.4 & 1.06 & 20.00 & 24.0 & 20.4 & 19.2 & 15.3 \\
\hline & 119 & 100 & 31.8 & 150 & 160 & 4.4 & 1.06 & 21.40 & 23.0 & 19.6 & 18.4 & 14.7 \\
\hline & 120 & 100 & 30.4 & 150 & 160 & 4.4 & 1.65 & 27.30 & 22.5 & 22.2 & 18.0 & 16.7 \\
\hline & 121 & 100 & 28.4 & 150 & 160 & 4.4 & 1.65 & 27.70 & 21.7 & 21.5 & 17.4 & 16.1 \\
\hline & 122 & 100 & 34.5 & 150 & 160 & 4.4 & 1.65 & 28.30 & 24.0 & 23.7 & 19.2 & 17.8 \\
\hline & 123 & 100 & 31.8 & 150 & 160 & 4.4 & 1.65 & 31.10 & 23.0 & 22.7 & 18.4 & 17.1 \\
\hline \multirow{4}{*}{ Han et al. (2001) [46] } & 124 & 100 & 39.6 & 170 & 270 & 1.5 & 1.10 & 83.50 & 49.1 & 41.6 & 39.3 & 31.2 \\
\hline & 125 & 100 & 30.6 & 170 & 270 & 2 & 1.10 & 65.20 & 43.2 & 36.6 & 34.5 & 27.4 \\
\hline & 126 & 100 & 32.6 & 170 & 270 & 2 & 1.10 & 60.60 & 44.6 & 37.7 & 35.6 & 28.3 \\
\hline & 127 & 100 & 31.2 & 170 & 270 & 3 & 1.10 & 42.70 & 43.6 & 36.9 & 34.9 & 27.7 \\
\hline
\end{tabular}

Note: $b=$ the width of cross-section, $d=$ effective depth, $a=$ shear span, $\rho_{\mathrm{w}}=$ longitudinal reinforcement ratio. 


\section{References}

1. Wu, H.; Xiao, J.; Liang, C.; Ma, Z. Properties of Cementitious Materials with Recycled Aggregate and Powder both from Clay Brick Waste. Buildings 2021, 11, 119. [CrossRef]

2. Makul, N.; Fediuk, R.; Amran, M.; Zeyad, A.; de Azevedo, A.; Klyuev, S.; Vatin, N.; Karelina, M. Capacity to Develop Recycled Aggregate Concrete in South East Asia. Buildings 2021, 11, 234. [CrossRef]

3. Tam, V.W.Y.; Soomro, M.; Evangelista, A.C.J. A Review of Recycled Aggregate in Concrete Applications (2000-2017). Constr. Build. Mater. 2018, 172, 272-292. [CrossRef]

4. Liew, K.M.; Sojobi, A.O.; Zhang, L.W. Green Concrete: Prospects and Challenges. Constr. Build. Mater. 2017, 156, 1063-1095. [CrossRef]

5. Meddah, M.S.; Al-Harthy, A.; Ismail, M.A. Recycled Concrete Aggregates and Their Influences on Performances of Low and Normal Strength Concretes. Buildings 2020, 10, 167. [CrossRef]

6. Al Ajmani, H.; Suleiman, F.; Abuzayed, I.; Tamimi, A. Evaluation of Concrete Strength Made with Recycled Aggregate. Buildings 2019, 9, 56. [CrossRef]

7. Shaikh, F. Mechanical and Durability Properties of Green Star Concretes. Buildings 2018, 8, 111. [CrossRef]

8. Junak, J.; Sicakova, A. Effect of Surface Modifications of Recycled Concrete Aggregate on Concrete Properties. Buildings 2018, 8, 2. [CrossRef]

9. Kisku, N.; Joshi, H.; Ansari, M.; Panda, S.; Nayak, S.; Dutta, S. A Critical Review and Assessment for Usage of Recycled Aggregate as Sustainable Construction Material. Constr. Build. Mater. 2017, 131, 721-740. [CrossRef]

10. de Brito, J.; Ferreira, J.G.; Pacheco, J.; Soares, D.; Guerreiro, M. Structural, Material, Mechanical and Durability Properties and Behaviour of Recycled Aggregates Concrete. J. Build. Eng. 2016, 6, 1-16. [CrossRef]

11. Kou, S.-C.; Poon, C.S. Effect of the Quality of Parent Concrete on the Properties of High Performance Recycled Aggregate Concrete. Constr. Build. Mater. 2015, 77, 501-508. [CrossRef]

12. Rao, A.; Jha, K.N.; Misra, S. Use of Aggregates from Recycled Construction and Demolition Waste in Concrete. Resour. Conserv. Recycl. 2007, 50, 71-81. [CrossRef]

13. Silva, F.; Delgado, J.; Azevedo, A.; Lima, A.; Vieira, C. Preliminary Analysis of the Use of Construction Waste to Replace Conventional Aggregates in Concrete. Buildings 2021, 11, 81. [CrossRef]

14. Behera, M.; Bhattacharyya, S.; Minocha, A.; Deoliya, R.; Maiti, S. Recycled Aggregate from C\&D Waste \& Its Use in Concrete-A Breakthrough Towards Sustainability in Construction Sector: A Review. Constr. Build. Mater. 2014, 68, 501-516.

15. Butler, L.; West, J.S.; Tighe, S.L. Effect of Recycled Concrete Coarse Aggregate from Multiple Sources on the Hardened Properties of Concrete with Equivalent Compressive Strength. Constr. Build. Mater. 2013, 47, 1292-1301. [CrossRef]

16. Xiao, J.; Li, J.; Zhang, C. Mechanical Properties of Recycled Aggregate Concrete under Uniaxial Loading. Cem. Concr. Res. 2005, 35, 1187-1194. [CrossRef]

17. Buyle-Bodin, F.; Hadjieva-Zaharieva, R. Influence of Industrially Produced Recycled Aggregates on Flow Properties of Concrete. Mater. Struct. 2002, 35, 504-509. [CrossRef]

18. Silva, R.; de Brito, J.; Dhir, R. Properties and Composition of Recycled Aggregates from Construction and Demolition Waste Suitable for Concrete Production. Constr. Build. Mater. 2014, 65, 201-217. [CrossRef]

19. Ismail, S.; Ramli, M. Influence of Surface-Treated Coarse Recycled Concrete Aggregate on Compressive Strength of Concrete. World Acad. Sci. Eng. Technol. Int. J. Civ. Environ. Struct. Constr. Archit. Eng 2014, 8, 862-866.

20. Tam, V.W.; Tam, C.M.; Le, K. Removal of Cement Mortar Remains from Recycled Aggregate Using Pre-Soaking Approaches. Resour. Conserv. Recycl. 2007, 50, 82-101. [CrossRef]

21. Kou, S.-C.; Poon, C.S. Properties of Concrete Prepared with Pva-Impregnated Recycled Concrete Aggregates. Cem. Concr. Compos. 2010, 32, 649-654. [CrossRef]

22. Fathifazl, G.; Razaqpur, A.; Isgor, O.B.; Abbas, A.; Fournier, B.; Foo, S. Shear Capacity Evaluation of Steel Reinforced Recycled Concrete (Rrc) Beams. Eng. Struct. 2011, 33, 1025-1033. [CrossRef]

23. Katz, A. Treatments for the Improvement of Recycled Aggregate. J. Mater. Civ. Eng. 2004, 16, 597-603. [CrossRef]

24. Li, J.; Xiao, H.; Zhou, Y. Influence of Coating Recycled Aggregate Surface with Pozzolanic Powder on Properties of Recycled Aggregate Concrete. Constr. Build. Mater. 2009, 23, 1287-1291. [CrossRef]

25. Sogo, M.; Sogabe, T.; Maruyama, I.; Sato, R.; Kawai, K. Shear Behavior of Reinforced Recycled Concrete Beams. In Proceedings of the International RILEM Conference on the Use of Recycled Materials in Buildings and Structures, Barcelona, Spain, 8-11 November 2004.

26. Etxeberria, M.; Mari, A.; Vázquez, E. Recycled Aggregate Concrete as Structural Material. Mater. Struct. 2007, 40, 529-541. [CrossRef]

27. González-Fonteboa, B.; Martínez-Abella, F. Shear Strength of Recycled Concrete Beams. Constr. Build. Mater. 2007, 21, 887-893. [CrossRef]

28. Knaack, A.M.; Kurama, Y.C. Behavior of Reinforced Concrete Beams with Recycled Concrete Coarse Aggregates. J. Struct. Eng. 2014, 141, B4014009. [CrossRef]

29. Ignjatović, I.; Marinković, S.B.; Tošić, N. Shear Behaviour of Recycled Aggregate Concrete Beams with and without Shear Reinforcement. Eng. Struct. 2017, 141, 386-401. [CrossRef] 
30. Arezoumandi, M.; Smith, A.; Volz, J.S.; Khayat, K. An Experimental Study on Shear Strength of Reinforced Concrete Beams with 100\% Recycled Concrete Aggregate. Constr. Build. Mater. 2014, 53, 612-620. [CrossRef]

31. Arezoumandi, M.; Drury, J.; Volz, J.S.; Khayat, K. Effect of Recycled Concrete Aggregate Replacement Level on Shear Strength of Reinforced Concrete Beams. ACI Mater. J. 2015, 112, 559. [CrossRef]

32. Rahal, K.; Alrefaei, Y. Shear Strength of Longitudinally Reinforced Recycled Aggregate Concrete Beams. Eng. Struct. 2017, 145, 273-282. [CrossRef]

33. Etman, E.E.; Afefy, H.M.; Baraghith, A.T.; Khedr, S.A. Khedr. Improving the Shear Performance of Reinforced Concrete Beams Made of Recycled Coarse Aggregate. Constr. Build. Mater. 2018, 185, 310-324. [CrossRef]

34. Pradhan, S.; Kumar, S.; Barai, S.V. Shear Performance of Recycled Aggregate Concrete Beams: An Insight for Design Aspects Constr. Build. Mater. 2018, 178, 593-611. [CrossRef]

35. Wardeh, G.; Ghorbel, E. Shear Strength of Reinforced Concrete Beams with Recycled Aggregates. Adv. Struct. Eng. 2019, 22, 1938-1951. [CrossRef]

36. Yun, H.-D.; Choi, W.-C. Shear Strength of Reinforced Recycled Aggregate Concrete Beams without Shear Reinforcements. J. Civ. Eng. Manag. 2017, 23, 76-84. [CrossRef]

37. Tošić, N.; Marinković, S.; Ignjatović, I. A Database on Flexural and Shear Strength of Reinforced Recycled Aggregate Concrete Beams and Comparison to Eurocode 2 Predictions. Constr. Build. Mater. 2016, 127, 932-944. [CrossRef]

38. Sadati, S.; Arezoumandi, M.; Khayat, K.; Volz, J.S. Shear Performance of Reinforced Concrete Beams Incorporating Recycled Concrete Aggregate and High-Volume Fly Ash. J. Clean. Prod. 2016, 115, 284-293. [CrossRef]

39. Katkhuda, H.; Shatarat, N. Shear Behavior of Reinforced Concrete Beams Using Treated Recycled Concrete Aggregate. Constr. Build. Mater. 2016, 125, 63-71. [CrossRef]

40. Kim, S.-W.; Jeong, C.-Y.; Lee, J.-S.; Kim, K.-H. Size Effect in Shear Failure of Reinforced Concrete Beams with Recycled Aggregate. J. Asian Archit. Build. Eng. 2013, 12, 323-330. [CrossRef]

41. Choi, H.; Yi, C.; Cho, H.; Kang, K. Experimental Study on the Shear Strength of Recycled Aggregate Concrete Beams. Mag. Concr. Res. 2010, 62, 103-114. [CrossRef]

42. Sato, R.; Maruyama, I.; Sogabe, T.; Sogo, M. Flexural Behavior of Reinforced Recycled Concrete Beams. J. Adv. Concr. Technol. 2007, 5, 43-61. [CrossRef]

43. Kanhakorn, P.; Watanee, R.; Rerksamosorn, W.; Inmontien, N.; Tippakdee, S.; Thanongsak, I.; Monthian, S.; Wattanapanich, C. Estimation of Shear Behaviour for Recycled Aggregate Concrete Using Digital Image Correlation (Wu-Dic). J. King Mongkut's Univ. Technol. North Bangk. 2021, 33, 4.

44. Imjai, T.; Guadagnini, M.; Garcia, R.; Pilakoutas, K. A Practical Method for Determining Shear Crack Induced Deformation in Frp Rc Beams. Eng. Struct. 2016, 126, 353-364. [CrossRef]

45. González-Fonteboa, B.; Martínez-Abella, F.; Martínez-Lage, I.; Eiras-López, J. Structural Shear Behaviour of Recycled Concrete with Silica Fume. Constr. Build. Mater. 2009, 23, 3406-3410. [CrossRef]

46. Han, B.C.; Yun, H.D.; Chung, S.Y. Shear Capacity of Reinforced Concrete Beams Made with Recycled-Aggregate. Spec. Publ. 2001, $200,503-516$. 